\title{
Adding pieces to the puzzle: insights into diversity and distribution patterns of Cumacea (Crustacea: Peracarida) from the deep North Atlantic to the Arctic Ocean
}

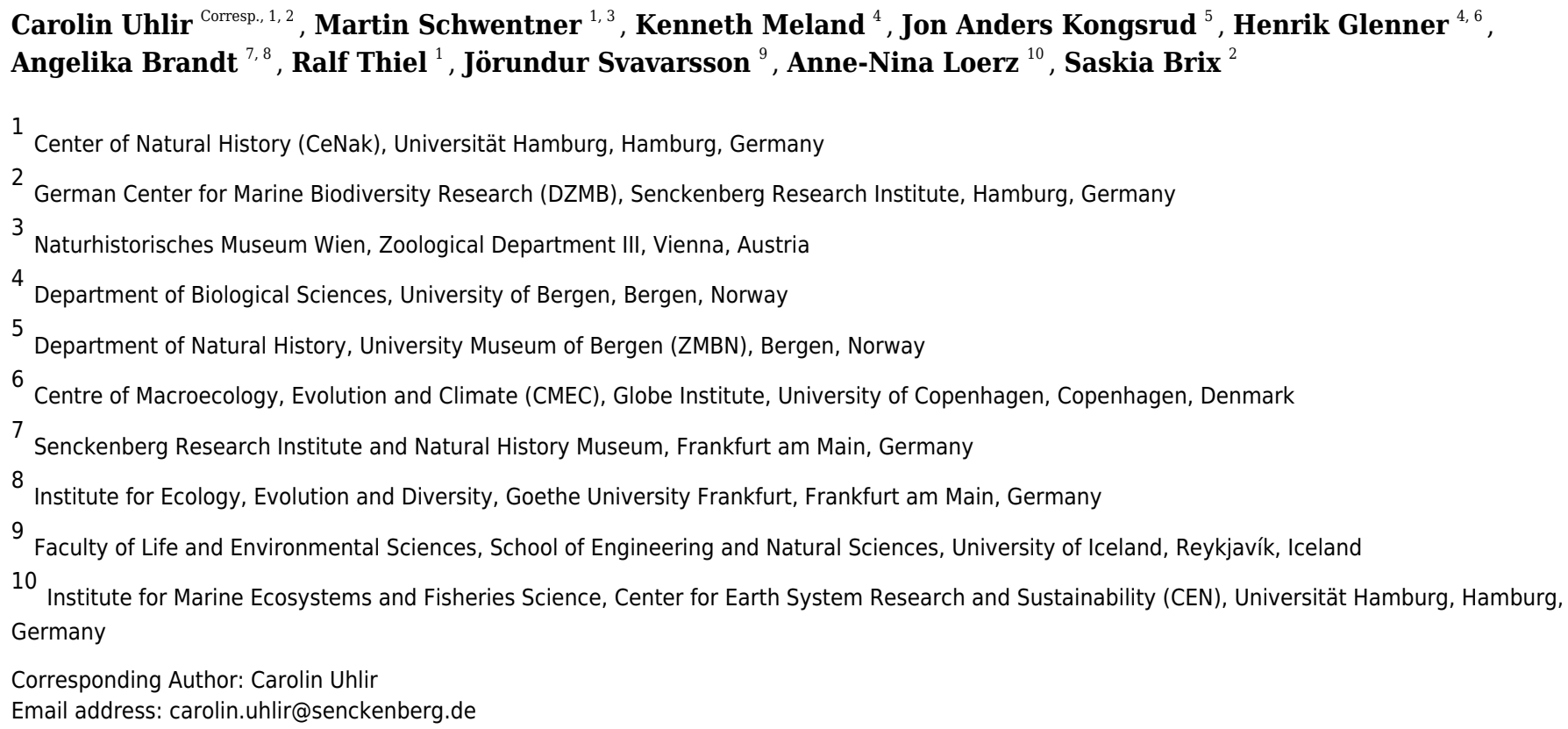

The Nordic Seas have one of the highest water-mass diversities in the world, yet large knowledge gaps exist in biodiversity structure and biogeographical distribution patterns of the deep macrobenthic fauna. This study focuses on the marine bottom-dwelling peracarid crustacean taxon Cumacea from northern waters, using a combined approach of morphological and molecular techniques to present one of the first insight s into genetic variability of this taxon. In total, 947 specimens were assigned to 77 morphologically differing species, representing all seven known families from the North Atlantic. 131 specimens were studied genetically (16S rRNA) and divided into 53 putative species by species delimitation methods (GMYC and ABGD). In most cases, morphological and molecular-genetic delimitation was fully congruent, highlighting the overall success and high quality of both approaches. Differences were due to eight instances resulting in either ecologically driven morphological diversification of species or morphologically cryptic species, uncovering hidden diversity. An interspecific genetic distance of at least $8 \%$ was observed with a clear barcoding gap for molecular delimitation of cumacean species. Combining these findings with data from public databases and specimens collected during different international expeditions revealed a change in the composition of taxa from a Northern Atlantic-boreal to an Arctic community. The Greenland-Iceland-Scotland-Ridge 
(GIS-Ridge) acts as a geographical barrier and/or predominat e water masses correspond well with cumacean taxa dominance. A closer investigation on species level revealed occurrences across multiple ecoregions or patchy distributions within defined ecoregions. 
2 Adding pieces to the puzzle: insights into diversity

3 and distribution patterns of Cumacea (Crustacea:

4 Peracarida) from the deep North Atlantic to the Arctic

5 Ocean

Carolin Uhlir ${ }^{1,2}$; Martin Schwentner ${ }^{1,3} ;$ Kenneth Meland $^{4}$; Jon Anders Kongsrud ${ }^{5} ;$ Henrik $^{2}$ Glenner $^{4,6}$; Angelika Brandt ${ }^{7,8}$; Ralf Thiel ${ }^{1}$; Jörundur Svavarsson ${ }^{9}$, Anne-Nina Loerz ${ }^{10}$; Saskia Brix $^{2}$

${ }^{1}$ Center of Natural History (CeNak), Universität Hamburg, Germany

${ }^{2}$ German Center for Marine Biodiversity Research (DZMB), Senckenberg Research Institute, Hamburg, Germany

${ }^{4}$ Department of Biological Sciences, University of Bergen, Bergen, Norway

${ }^{5}$ Department of Natural History, University Museum of Bergen (ZMBN), Norway

${ }^{6}$ Centre of Macroecology, Evolution and Climate (CMEC), Globe Institute, University of Copenhagen, Copenhagen, Denmark

${ }^{7}$ Senckenberg Research Institute and Natural History Museum, Frankfurt am Main, Germany

${ }^{8}$ Institute for Ecology, Evolution and Diversity, Goethe University Frankfurt, Frankfurt am Main, Germany

${ }^{9}$ Faculty of Life and Environmental Sciences, School of Engineering and Natural Sciences, University of Iceland, Reykjavík, Iceland

${ }^{10}$ Institute for Marine Ecosystems and Fisheries Science, Center for Earth System Research and Sustainability (CEN), Universität Hamburg, Hamburg, Germany

Corresponding Author:

Carolin Uhlir ${ }^{1,2}$

Südstrand 44, 26382 Wilhelmshaven, Germany

Email address: carolin.uhlir@senckenberg.de

\section{Abstract}

The Nordic Seas have one of the highest water-mass diversities in the world, yet large knowledge gaps exist in biodiversity structure and biogeographical distribution patterns of the deep macrobenthic fauna. This study focuses on the marine bottom-dwelling peracarid crustacean taxon Cumacea from northern waters, using a combined approach of morphological and molecular techniques to present one of the first insights into genetic variability of this taxon. In total, 947 specimens were assigned to 77 morphologically differing species, representing all 
seven known families from the North Atlantic. 131 specimens were studied genetically (16S rRNA) and divided into 53 putative species by species delimitation methods (GMYC and ABGD). In most cases, morphological and molecular-genetic delimitation was fully congruent, highlighting the overall success and high quality of both approaches. Differences were due to eight instances resulting in either ecologically driven morphological diversification of species or morphologically cryptic species, uncovering hidden diversity. An interspecific genetic distance of at least $8 \%$ was observed with a clear barcoding gap for molecular delimitation of cumacean species. Combining these findings with data from public databases and specimens collected during different international expeditions revealed a change in the composition of taxa from a Northern Atlantic-boreal to an Arctic community. The Greenland-Iceland-Scotland-Ridge (GISRidge) acts as a geographical barrier and/or predominate water masses correspond well with cumacean taxa dominance. A closer investigation on species level revealed occurrences across multiple ecoregions or patchy distributions within defined ecoregions.

\section{Introduction}

The ocean surrounding Iceland and its adjacent waters have one of the world's highest diversities of water masses (Hansen \& Østerhus, 2000). The hydrography of the area is rather complex as several primary water masses meet and often overlay each other (Malmberg \& Valdimarsson, 2003; Brix \& Svavarsson, 2010; Meißner et al., 2014). According to these hydrographic features, benthic habitats are characterized by depth gradients, water-mass parameters and habitat structure (Meißner et al., 2014). Thus, environmental data is important to help understand the driving forces of species' distribution patterns.

It is widely accepted that 'Arctic' water masses are distinguished from 'Subarctic' water masses by their origin from the upper 250-300 $\mathrm{m}$ of the Arctic Ocean, whereas the latter describe a mixture of polar and non-polar (Atlantic or Pacific) water masses (Dunbar, 1951, 1972; Curtis, 1975). Composition and distribution of benthic organisms in the Arctic Ocean is related to water masses, but also to the geological history (Bluhm et al., 2011; Mironov \& Krylova, 2013). The Fram Strait between North-East Greenland and Svalbard is the only deep-reaching connection to the Arctic Basin (sill depth $>2200 \mathrm{~m}$ ). In the Icelandic region, the Greenland-Iceland-Scotland Ridge (GIS-Ridge) is a natural border for benthic organisms extending from East Greenland to Scotland and forming a continuous barrier between the North Atlantic, the North European and Siberian Seas and the Arctic Ocean north of the ridge (Hansen \& Østerhus, 2000). It acts as a transition region exhibiting major temperature differences between water masses of the warmer North Atlantic and colder Greenland, Iceland and Norwegian Sea (GIN-Seas, also termed the Nordic Seas; Brix et al., 2018a). Gaps along this ridge allow deep-water exchange between East Greenland and Iceland across the Denmark Strait and the Faroe Bank Channel between the Faroe Islands and the Faroe Bank, which, at $860 \mathrm{~m}$, is the deepest connection between the $>4000 \mathrm{~m}$ deep basins separated by the GIS-Ridge (Brix \& Svavarsson, 2010). Earlier studies in this region revealed a trend of north-south separation of benthic crustacean species distributions 
80 (Weisshappel \& Svavarsson, 1998; Weisshappel, 2000; Weisshappel, 2001) and further outlined

81 82

the ridge as a potential pathway for the dispersal of shelf fauna from Norway towards Iceland (Brix et al., 2018a).

Crustaceans of the taxon Peracarida Calman, 1904 often form a major fraction of macrobenthic communities in terms of diversity and abundance in Arctic and Subarctic waters (Brandt, 1997; Conlan et al., 2008; Stransky \& Svavarsson, 2010). They are characterized by a marsupium, a brood pouch on the ventral side of the carapace of the mature female (Westheide \& Rieger, 1996; Silva, 2016). Juveniles hatch as a manca stage by skipping the planktonic stage. In this study, we will focus on the peracarid taxon Cumacea Krøyer, 1846, which are primarily marine bottom-dwelling benthic crustaceans, spending most of their life buried in or close to the sediment with an adapted morphology for a sediment-water-interface lifestyle. Thus, cumaceans are assumed to be restricted in their dispersal abilities and are most likely not able to drift over vast distances (Rex, 1981; Wilson \& Hessler, 1987).

Most species have a specialized feeding strategy as detritus or filter feeders. Some more derived taxa have evolved in association with other epibenthic organisms such as sponges or corals and established a strategy as that of scavengers and micro-predators (e.g. Campylaspis G.O.

Sars, 1865) with modified mouth parts as piercing organs (Foxon, 1936; Jones, 1976; Petrescu et al., 2009).

Currently there are over 1800 accepted cumacean species recorded worldwide categorized into eight families (Watling \& Gerken, 2019). Approximately 250 cumacean species are recorded in the high-latitude Arctic regions and at least 19 species are known as Arctic endemic species (Vassilenko, 1989). According to the most recent studies on biogeographical patterns of cumaceans in respect to water masses in the Arctic, the families Diastylidae Bate, 1856 and Nannastacidae Bates, 1966 are the most species rich and most widely distributed (Vassilenko, 1989; Watling \& Gerken, 2005). The family Leuconidae G.O. Sars, 1878 is the second most species rich taxon and commonly found in colder waters (Vassilenko, 1989; Haye et al., 2004; Watling \& Gerken, 2005). The predominantly warm-water family Bodotriidae Scott, 1901 and temperate cold-water family Lampropidae G.O. Sars, 1878 contain fewer representatives, but also some endemic Arctic species. Vassilenko (1989) divided the cumacean fauna in the Arctic Ocean into six biogeographic groups, listed in order of decreasing number of species: BorealArctic, Arctic, Atlantic boreal, Pacific boreal, Atlantic subtropical-boreal and Amphiboreal species. In a later publication (Vassilenko, 2002) the Arcto-Atlantic bathyal species group was added to include widespread species from North Atlantic intermediate to near-bottom Arctic water at the continental slope of Arctic Ocean. A complete species list of biogeographic species' distributions is provided by Vassilenko (1989), Vassilenko \& Brandt (1996), Watling \& Gerken (2005) and Watling (2009). A reference catalogue of previous studies of the cumacean fauna in North Atlantic and the Atlantic sector of the Arctic Ocean is presented in Vassilenko (1989). In Subarctic and Arctic Ocean regions, the typically patchy distribution patterns of many cumacean species correspond well with the distribution of major water masses (Gerken \& Watling, 1999; Gage et al., 2004; Watling, 2009), as well as local sediment grain size as most 
120

121

122

123

124

125

126

127

128

129

130

131

132

133

134

135

136

137

138

139

140

141

142

143

144

145

146

147

148

149

150

151

152

153

154

155

156

157

158

cumaceans feed by scraping sand grains (Foxon, 1936). Distribution patterns are less controlled by depth; thus, most species are not restricted to deep-sea areas (Hansen, 1920; Haye, 2002; Watling \& Gerken, 2005). The same pattern is assumed for another peracarid taxon, Tanaidacea Dana, 1849 (Błażewicz-Paszkowycz \& Siciński, 2014), whereas species distributions of Isopoda Latreille, 1817 seem to be mostly driven by depth and related factors (Schnurr et al., 2014; Brix et al., 2018b). A recent study by Loerz et al. (2021) about amphipods supports water-mass properties to be the main factor shaping species distributions at the boundary between the North Atlantic and Arctic waters as well as the prominent submarine Greenland-Iceland-Faroe Ridge playing a major role in hindering the exchange of deep-sea species between northern and southern deep-sea basins. Large numbers of cumaceans are assumed to remain undiscovered in greater depths, as shelf fauna has been studied to a larger extent and, thus, the abundance and diversity of cumaceans is probably underestimated (Jones, 1972; Vassilenko, 1989; Gage et al., 2004 and references therein).

This study aims to present a first insight into biogeographical species diversity of cumaceans from North Atlantic to Arctic waters. The integration of species occurrence records from public databases such as the Global Ocean Biogeographic Information System (OBIS) and the Marine Area database for Norwegian waters (MAREANO) will build the baseline for a species catalogue in the investigated area. New occurrence records provided by the present study will contribute to a better understanding of species distribution ranges for future research on cumacean distribution patterns. Morphological and molecular techniques are used for an integrative taxonomy approach and will increase the knowledge of genetic and morphological variability of this understudied taxon.

\section{Materials \& Methods}

\section{Sampling and study-area properties}

The study area includes the northernmost part of the North Atlantic, extending across the GINSeas up to the Arctic Ocean. The main bulk of specimens included in this study was collected during the following international projects and expeditions: IceAGE (Icelandic marine Animals: Genetics and Ecology; Cruise M85/3 in 2011; Brix et al., 2014a; Meißner et al., 2018), which is a follow up of the BIOFAR (Biology of the Faroe Islands; Nørrevang et al., 1994; Gerken \& Watling, 1999) and the BIOICE project (Benthic Invertebrates of Icelandic waters; Omarsdottir

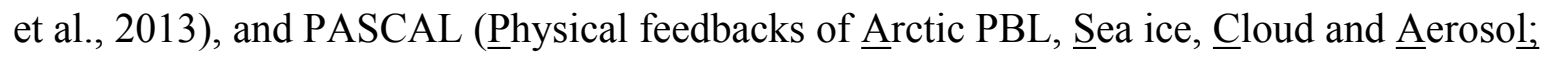
Cruise PS106/1 in 2017; Macke \& Flores, 2018) onboard the RVs Meteor and Polarstern, focusing on remote shelf-break and deep-sea habitats within a depth range of $579-2748 \mathrm{~m}$ (Fig. 1). Grant support and field permits are available under BR3843/3-1 and AWI_PS106_00. Additional specimens from the Norwegian Sea and waters off Svalbard sampled by the MAREANO program (Thorsnes, 2009) and the University of Bergen were included (Table 1). Cumaceans were sampled in large amounts in all projects. 
159

160

161

162

163

164

165

166

167

168

169

170

171

172

173

174

175

176

177

178

179

180

181

182

183

184

185

186

187

188

189

190

191

192

193

194

195

196

197

198

Temperature and salinity were considered as hydrographic variables for the evaluation of watermass characteristics, which were available for IceAGE areas (http://www.vliz.be/en/imis?module=dataset\&dasid=6211) and PASCAL stations (https://doi.pangaea.de/10.1594/PANGAEA.881579) measured just off the sea floor with a conductivity-temperature-depth profiler (CTD) (see Brix et al. 2012, Brix \& Devey, 2019). Each area and station was allocated to a defined water mass according to the definition of Schlichtholz \& Houssais (2002), which is applicable for the Fram Strait region and, thus, the entrance to the deep Arctic Eurasian Basin. For the GIN-Seas around Iceland, the definitions as described by Hansen \& Østerhus's (2000), Brix \& Svavarsson (2010) and Ostmann et al. (2014) have been used as baseline (Table S1). The records were manually divided into eight ecoregions based on their predominate water-mass characteristics after the combined definitions of Curtis (1975), Spalding et al. (2007) and Piepenburg (2011): Warm North Atlantic water mass (North Atlantic Ocean, ecoregion 4), intermediate Subarctic water mass (East Greenland Sea, 2; Norwegian Sea, 5; Barents Sea, 7) and cold Arctic water mass (Arctic Basin, 1; Kara Sea, 8; North Greenland Sea, 3; White Sea, 6).

\section{Sampling data and sample treatment}

Specimens were obtained using different types of benthic sampling gear. Most frequently applied was the Rothlisberg-Pearcy Epibenthic sled (RP-EBS, Rothlisberg \& Pearcy, 1976; Brattegard \& Fosså, 1991), equipped with a net of $500 \mu \mathrm{m}$ mesh size and ending in a collecting cod end of $300 \mu \mathrm{m}$ mesh size. Different from the standard deployment protocols as outlined in Brenke (2005), the sampling during the PASCAL expedition was conducted while the vessel was attached to an ice floe during a two-week passive drifting according to the ocean's current with an average drift velocity of $0.12 \mathrm{kn}$. Furthermore, the Camera-Epibenthic sled (C-EBS; Brandt et al., 2013), the Brenke-Sled (Brenke, 2005) and the Giant Box corer (BC; Hessler \& Jumars, 1974) were deployed. A detailed description of the sampling design is given in Brix et al. (2014a). Once the deployed gear was on board, the haul was carefully floated in seawater and evenly decanted gently over a series of sieves with mesh sizes of $1 / 0.5 / 0.3 \mathrm{~mm}$, washed with sea water on a sieving table and bulk-fixed in precooled $96 \%$ undenatured ethanol. All samples were treated as described in Riehl et al. (2014), ensuring that the samples stayed consistently cooled. The samples were sorted either directly on board or afterwards in the laboratories of the German Center for Marine Biodiversity Research (DZMB, Senckenberg am Meer, Hamburg).

\section{Morphological specimen identification}

A total of 947 specimens (Table S2) were determined to the lowest possible taxonomic rank, based primarily on original species descriptions (e.g., Hansen, 1920; Sars GO, 1900). Species identifications were conducted at the Department of Biological Sciences (University of Bergen, Norway) and DZMB Hamburg using either a ZEISS SteREO Discovery.V8 or Leica MZ12.5 
199

200

201

202

203

204

205

206

207

208

209

210

211

212

213

214

215

216

217

218

219

220

221

222

223

224

225

226

227

228

229

230

231

232

233

234

235

236

237

238

dissecting microscope. Dissected pereopods and mouth parts were assessed under a ZEISS Primo Star compound microscope. High quality pictures with depth of focus were taken with a Leica DFC400 digital compound microscope camera using the Z-stacking option in the Leica Application Suite imaging software. Current authoritative classification follows the catalogue World Cumacea Database (http://www.marinespecies.org/cumacea/, Watling \& Gerken, 2019) in the World Register of Marine Species (WoRMS, 2019). Additionally, comparative museums' material has been obtained from the Center of Natural History Hamburg (CeNak) and the University Museum of Bergen (ZMBN).

\section{Molecular methods}

\section{DNA extraction, PCR amplification and sequencing}

To delimit putative species genetically, DNA extraction and PCR amplification were performed in the laboratories of UoB in Bergen and CeNak in Hamburg. To ascertain that a morphological voucher retained intact, DNA extraction was only performed if at least two individuals were morphologically assigned to the same species. Three different manual workflow kits (DNeasy® Blood and Tissue Kit, QIAGEN®; E.Z.N.A. ${ }^{\circledR}$ Mollusc DNA Kit, Omega Bio-tek, Inc., Norcross, GA, USA; Marine Animal Tissue Genomic DNA Extraction Kit, Neo-Biotech) and one chelating resin (Chelex ${ }^{\circledR}$ 100; Bio-Rad Laboratories, CA, USA) were used by following the manufacturer's instructions, except for the subsequent cleanup step within the DNeasy Blood and Tissue Kit, which was conducted using the AMPure XP beads, CBeckman Coulter. All DNA extracts were stored immediately after processing at $-20{ }^{\circ} \mathrm{C}$. Nucleic acid concentration $[\mathrm{ng} / \mu \mathrm{l}]$ and purity of $1 \mu \mathrm{L}$ DNA extract was measured with a Thermo Scientific NanoDrop ${ }^{\mathrm{TM}}$ 2000 Spectrophotometer for all extractions. When the measured concentration exceeded $20 \mathrm{ng} / \mu \mathrm{l}$, DNA template was diluted 1:10 with $\mathrm{ddH}_{2} \mathrm{O}$.

PCR reactions were performed in a reaction volume of $15 \mu \mathrm{L}$, consisting of $0.05 \mu \mathrm{L}$ DreamTaq DNA Polymerase, $1.5 \mu 1$ DreamTaq Buffer (Thermo Fisher Scientific, Germany), $0.12 \mu 1$ dNTPs mix (25 mM each), $1.5 \mu \mathrm{l}$ of each primer (10 mM each) and 1-2 $\mu \mathrm{L}$ DNA extract. Two different sets of 16S rRNA gene primers were utilized, 16Sar-L (5'-CGCCTGTTTATCAAAAACAT-3', Palumbi et al., 1991) and 16Sb (5'-CTCCGGTTTGAACTCAGATCA-3', Xiong \& Kocher, 1991), which was particularly successful for species of the families Diastylidae, Lampropidae and Leuconidae, and 16SALh (5'-GTACTAAGGTAGCATA-3') and 16SCLr (5'ACGCTGTTAYCCCTAAAGTAATT-3', Rehm, 2007; Rehm, 2020), which yielded better results for the Bodotriidae, the Ceratocumatidae Calman, 1905 and some Nannastacidae. However, the latter results in a 200 bp shorter DNA fragment, thus these short sequences were included only in the phylogenetic analyses and were excluded from genetic distance analyses. PCR program had a reaction profile of $94^{\circ} \mathrm{C}(2 \mathrm{~min}),$.38 cycles of $94^{\circ} \mathrm{C}(20 \mathrm{sec}),. 46^{\circ} \mathrm{C}(10 \mathrm{sec}$. and $65^{\circ} \mathrm{C}(1 \mathrm{~min}$. $)$ and final extension step of $65^{\circ} \mathrm{C}(8 \mathrm{~min}$. $)$ was applied. PCR products were purified by incubating $11-13 \mu \mathrm{L}$ PCR product with $0.8 \mu \mathrm{L}$ FastAP $(1 \mathrm{U} / \mu \mathrm{L})$ and $0.4 \mu \mathrm{L}$ 
239 Exonuclease I $(20 \mathrm{U} / \mu \mathrm{L})$ (both Thermo Fisher Scientific $\left.{ }^{\mathrm{TM}}\right)$ in $37{ }^{\circ} \mathrm{C}$ for $15 \mathrm{~min}$ and $80{ }^{\circ} \mathrm{C}$ for 15

240 min. Bidirectional sequencing was performed with the respective PCR primer set, either with

241 Macrogen Europe, Inc (Amsterdam-Zuidoost, Netherlands) or Eurofins Genomics Germany

$242 \mathrm{GmbH}$. Out of 123 extracted specimens, 80 yielded sequence data of sufficient quality to be

243 included in the molecular species delimitation (Table 2). These sequences can be accessed via

244 GenBank and BoLD (dx.doi.org/10.5883/DS-ICECU).

\section{Phylogenetic analyses}

Raw sequences were assembled and manually curated in Geneious ${ }^{\circledR}$ version 9.8.1 (Kearse et al., 2012). Consensus sequences were generated and blasted against GenBank database to identify potential contaminant sequences (e.g., bacterial sequences). We further included 67 cumacean sequences published on GenBank, 51 sequences originating from North Atlantic cumaceans currently studied at the University Bergen as well as 16 from outside the study area (Table 2). Due to the large number of substitutions and indels, the alignment of all sequenced species included many long, ambiguously aligned regions, which would compromise the following analyses. For this reason, we split the data into four subsets of more closely related (and thus more similar) sequences, based on morphological family taxa and a preliminary phylogenetic analysis on the complete dataset (dataset I; Table 3). These family-based alignments had fewer ambiguities and gaps and were thus used for subsequent analyses. Alignments were calculated separately for each of these four subsets with MAFFT 7.402 (Katoh, 2002; Katoh \& Standley, 2013) on the CIPRES Science Gateway version 3.3 (Miller et al., 2010) using the L-INS-I algorithm and subsequently trimmed manually in BioEditC version 7.0.5.3 (Hall, 1999). One outgroup species (represented by a member of one of the respective other cumacean families) was included in the alignments for the phylogenetic analyses but removed to further improve the alignment for genetic distance analyses. the General Time Reversible Model with invariable sites and gamma distribution (GTR $+\mathrm{G}+\mathrm{I}$; Lanave, 1984; Rodriguez et al., 1990; Nylander et al., 2004) for all data sets. Subsequent phylogenetic analyses were performed with MrBayes version 3.2.7a (Ronquist et al., 2012) with 'nruns $=4$ ' and 'nchains =6', $50 \times 106$ generations and a sample frequency of 5000. The first $25 \%$ of sampled trees were discarded as burn-in. The resulting consensus trees were visualized with FigTree version 1.4.4 (Rambaut, 2018a). Two different species delimitation methods were employed, one tree-based (general mixed Yule coalescent, GMYC, Pons et al., 2006) and one distance-based (automatic barcode gap discovery, ABGD, Puillandre et al., 2012). The single threshold model of GMYC was performed in R (R Core Team) for each of the four subsets. The required ultrametric trees were calculated with BEAST 2.5 (Bouckaert et al., 2019), employing the Yule coalescent prior, enforcing the ingroup as monophyletic and running the analyses for $30 * 106$ generations and sampling every 3000 th generation. Convergence was assessed in Tracer (Rambaut et al., 2018b) and the final tree 
279

280

281

282

283

284

285

286

287

288

289

290

291

292

293

294

295

296

297

298

299

300

301

302

303

304

305

306

307

308

309

310

311

312

313

314

315

316

317

produced with TreeAnnotator (Bouckaert et al., 2019), removing the first 25\% of generations as burn-in.

The relatively large number of potential singleton taxa could be problematic for tree-based species delimitation approaches. For ABGD, uncorrected $p$-distances were precomputed without an evolutionary substitution model in MEGA $X$ including transitions and transversions as substitution mutations and missing data was treated by pairwise deletion. Sequences shorter than $300 \mathrm{bp}$ were excluded. The web-based version of ABGD was used (https://bioinfo.mnhn.fr/abi/public/abgd/abgdweb.html), setting Pmin $=0.01$, Pmax $=0.1$, the relative gap width $(\mathrm{X})$ to 0.5 and the number of steps to 100 .

\section{Distribution maps}

For a general occurrence range overview, distribution maps were created using the software $\mathrm{R}$ version 3.5.3 and the PlotSvalbard package version 0.8.5 (Vihtakari, 2019) for each species. A single map incorporates the available georeferenced records from the open-access portal OBIS (OBIS, 2019; https://mapper.obis.org/, accessed 19/09/2019) and either the type locality or reference localities from earlier publications. Additionally, new occurrence records, not integrated in the OBIS platform, were added from published literature (e.g. Watling \& Gerken, 2005) as well as records from other publicly accessible occurrence record libraries (e.g. MAREANO platform, Table S3). The new OBIS dataset Icelandic Cumacea (ICECU) was created for IceAGE and PASCAL specimens (Uhlir et al., 2021; http://ipt.vliz.be/eurobis/resource?r=cumacea_pascal_iceage). Information on cumacean species sampled and identified by the MAREANO project are accessible for specific taxa via the species-list portal (http://webprod1.nodc.no:8080/marbunn_web/viewspecies).

\section{Results}

\section{Combined approach: Morphological and molecular species delimitation}

The 947 investigated specimens were assigned to 77 morphological species, representing all seven known families (Table S4). For 58 species, identification to a known species taxon was possible. In all other 19 cases, specimens were assigned to genus or family level, but clearly differed morphologically from all other species of these genera or families identified in our study. The largest number of species were assigned to the Nannastacidae (20 species), followed by the Diastylidae (19), the Lampropidae (14) and the Leuconidae (15). In terms of DNA quality and success rate, the Marine Animal Tissue Genomic DNA kit yielded the best results for the cumaceans and can, thus, be recommended for further studies on this taxon. In total, 131 specimens were included in the genetic analyses, representing 54 of the 77 morphologically identified species (Table 2). The Bayesian phylogenetic analysis of dataset I (all 
318

319

320

321

322

323

324

325

326

327

328

329

330

331

332

333

334

335

336

337

338

339

340

341

342

343

344

345

346

347

348

349

350

351

352

353

354

355

356

357

taxa) resulted in the monophyly of the Cumacea (posterior probability [pp] =1)(Fig. 2). Except for the Nannastacidae ( $p p=1$ ), families were not recovered as monophyletic (Fig. 3-6), but this was not surprising, as a single fastly evolving marker like $16 \mathrm{~S}$ is not suitable to properly resolve such deep nodes.

The ABGD analyses delimited 53 genetic lineages (representing putative species). With few exceptions, lineages were separated by a clear barcoding gap, with the vast majority of intralineage distances being $<1 \%$ and inter-lineage distances $>8 \%$ (mostly $15-45 \%$ ) (Fig. S1; Table S5-S12). Cases of intra-lineage $p$-distance exceeding 1\% were Diastylis rathkei Krøyer, 1841 (Dia07, 4 \%; Table S5-S6) and Hemilamprops cristatus G.O. Sars, 1870 (Lam05-A, 2 \%; Table S7-S8). GMYC resulted in nearly identical species delimitation, only Diastyloides biplicatus G.O. Sars, 1865 (Dia11) and Diastyloides serratus G.O. Sars, 1865 (Dia12) were grouped together (because these are separated by a genetic distance of $18 \%$, we consider this to be an artifact due to the high number of singletons [D. biplicatus is also singleton] and treat them separately in the following as suggested by AGBD).

Inconsistencies between morphological and molecular species delimitation occurred in eight cases, which are summarized in Table 4. In four cases, genetic divergence was higher than expected by prior morphological determination suggesting cryptic diversity. Cyclaspis longicaudata Sars, 1865 was split into two distinct lineages (Bod05, A-B; Table S9-S10) as were Leptostylis borealis Stappers, 1908 (Dia15, A-B; Table S5-S6) and Leptostylis sp. 1 (Dia17, AB; Table S5-S6). Eudorella truncatula Bate, 1856 was split into three lineages (Leu04, A-C; Table S11-S12). Conversely, Leucon (Leucon) aff. nathorsti Ohlin, 1901 (Leu09) and L. (L.) nathorsti (Leu08) were treated as two morphologically differing species based on prior determination following Hansen (1920) (Leu09 with rather pointy rostrum; two dorsolateral teeth on frontal lobe). However, the low genetic distance $(1 \%)$ suggests that they belong to the same lineage (Table S11-S12). Finally, two problematic cases highlighted the mismatch between morphological and genetic delimitation. First, Leptostylis longimana Sars, 1865 was genetically split into two morphologically cryptic lineages (Dia16, A-B; Table S5-S6), of which Dia16-A was collected close to the species' type locality on the continental shelf and a Norwegian fjord and Dia16-B from Arctic Polar Water (APW). Furthermore, Dia16-B was genetically identical to Leptostylis ampullacea Lilljeborg, 1855 (Dia14), which was collected in Icelandic waters (Norwegian Sea Arctic Intermediate Water, APW-NSAIW) more than $2500 \mathrm{~km}$ further north. However, after re-examination these specimens could barely be distinguished based only on weakly discriminating morphological characters following G.O. Sars (1900; clumsier form of body) from specimens identified as the original Leptostylis longimana (Dia16-A). Second, one species (Hemilamprops cf. cristatus; Lam05-B) morphologically very closely resembled Hemilamprops cristatus (Lam05-A) but was eventually differentiated based on a shorter rostrum and smaller, but more teeth within the serrated dorsal crest in Lam05-A. Also, genetic analyses suggested two lineages with strong divergence (23\% p-distance), however, the Lam05-A specimen (sequence ID ICE1-Lam018) from the Greenland slope in Subarctic waters (APWNSAIW), morphologically assigned to Lam05-B, clustered together with Lam05-A from the 
358

359

360

361

362

363

364

365

366

367

368

369

370

371

372

373

374

375

376

377

378

379

380

381

382

383

384

385

386

387

388

389

390

391

392

393

394

395

396

Norwegian continental shelf. All other Lam06 specimens were from Iceland Sea Overflow Water (ISOW) in the Iceland Basin

\section{Biogeographical data mining in OBIS}

Within the investigated area, a total of 11,714 occurrence records including 44,933 individual specimens were extracted from OBIS (9,151 records), literature and other databases $(2,270)$, and the new ICECU dataset added 293 records (Fig. 7). Out of these, about 6,200 records are in shelf regions up to $250 \mathrm{~m}$ depth, about 3,900 records in shelf-break regions between $250-1000 \mathrm{~m}$ and 639 records below $1000 \mathrm{~m}$ in the deep sea, excluding about 780 records with no available depth information. More than half of the specimens $(25,496)$ were classified on order level as 'Cumacea indet.', whereas 19,437 specimens were identified to family or a lower taxonomic level. In total, 109 known species are recorded, of which 18 species of five families were recorded for the first time on the OBIS platform within the ecoregions 1, 2, 4, 5 and 7 (Fig. 8). The amount of data and specimen records varied remarkably among the predefined ecoregions 18. Ecoregion 4 was assigned to North Atlantic water mass characteristics comprising the highest specimen count $(20,101)$, followed by ecoregion $5(11,664), 2(7,667)$ and $7(3,505)$, which are composed of a mixture of North Atlantic and Arctic water masses and were, thus, assigned to Subarctic water-mass characteristics. Arctic water-mass ecoregions 8 (858 specimens), 1 (232), 6 (490) and 3 (29) contributed the lowest specimen sampling effort. There was a general trend of decreasing number of taxa (species diversity) with fewer specimens following the northern extension of the North Atlantic Current (NAC). For example, out of 232 individual specimens in ecoregion 1, 203 were assigned to 30 different species, while ecoregion 8, one of the last ecoregions influenced by the NAC, had a higher sampling effort with 858 specimens, but a lower species diversity with 407 individuals assigned to 18 species.

\section{Species distribution patterns within ecoregions}

Overall, the composition of taxa was observed to change from a Northern Atlantic-boreal (ecoregion 4, 5, 7) to a typical Arctic community (2, 1, 8, 6, 3; Fig. 9). Investigating the composition of the most frequently occurring taxa in OBIS revealed that the taxon Diastylis rathkei was recorded in all ecoregions, followed by Campylaspis rubicunda Liljeborg, 1855, Diastylis goodsiri Bell, 1855 and Brachydiastylis resima Krøyer, 1846, which were recorded in seven of eight regions. Compared to other ecoregions of the same size, the Arctic Ocean and the area around Iceland are underrepresented in cumacean occurrence records. Currently available records in these ecoregions are restricted to 90 entries of 32 species. Within these records, the most frequently occurring species are Diastylis polaris, Sars, 1871, Leptostylis longimana, Platytyphlops semiornatus Fage, 1929, Campylaspis globosa Hansen, 1920, C. valleculate Jones, 1974, Leucon (Epileucon) spiniventris Hansen, 1920 and Platycuma holti Calman, 1905. 
397

398

399

400

401

402

403

404

405

406

407

408

409

410

411

412

413

414

415

416

417

418

419

420

421

422

423

424

425

426

427

428

429

430

431

432

433

434

435

\section{Faunistic mix in ICECU material}

The morphologically and genetically investigated material of the ICECU dataset corresponded well with the earlier observed trend in the OBIS dataset of high species diversity in the North Atlantic (ecoregion 4) with 45 representative, ecoregion-specific species (Fig. 10; Table 5). With the northern extension of the NAC, the representative species number decreases to seven in ecoregion 1 (Arctic Basin) and five in ecoregion 2 (East Greenland Sea). The number of shared species occurring in more than one ecoregion decreases with distance: While the adjacent ecoregion 4 and 5 share five species, ecoregion 4 and 1 only share one species (Campylaspis intermedia Hansen, 1920). The two species Platysympus typicus G.O. Sars, 1870 and Leucon (Alytoleucon) pallidus G.O. Sars, 1865 were recorded in all ecoregions. Comparing regional distribution patterns of families, a seamless shift in the relative composition along the GIS-Ridge could be observed (Fig. 9). The highest number of investigated specimens and species was recorded in stations located south of the Ridge in the Icelandic and Irminger Basins, which have warmer and more saline water masses (ISOW, Labrador Sea Water (LSW), North Atlantic Water (NAW); ecoregion 4) and were characterized by the families Lampropidae and Nannastacidae. Stations north of the Iceland-Faroe Ridge, the Denmark Strait and the on the Yermak Plateau north of Svalbard are influenced by colder and less saline water masses (APW, NSAIW, cold \& warm Norwegian Sea Deep Water NSDWc \& NSDWw; ecoregion 1, 2) and were mostly characterized by the families Diastylidae and Leuconidae. Representatives of the family Bodotriidae were only recorded in southern stations (Station 983, ISOW; 1057, LSW; 1072, NAW), as well as the Ceratocumatidae (1057, LSW; 1072, NAW) and the only representative specimen of the Pseudocumatidae G.O. Sars, 1878 (1057, LSW).

In correspondence with the OBIS data, Leptostylis cf. longimana (Dia16-B; Fig. 11-A) and Leptostylis ampullacea (Dia14; Fig. 11-B) were the most frequently recorded species, occurring at 13 out of 21 stations, followed by Diastylis polaris (Dia06; Fig. 11-C) and Leucon (Alytoleucon) pallidus (Leu05; Fig. 11-D) recorded at five stations each. Other wide-ranging species, such as Platysympus typicus (Lam13; Fig. 11-E) and Hemilamprops cristatus (Lam05; Fig. 11-F) were found across multiple ecoregions. A majority of the species were only present in samples from one or two stations. For characteristic boreal and Arctic taxa investigated in this study, such as Leptostylis borealis (Dia15; Fig. 12-A), L. (A.) pallidus (Leu05) or Hemilamprops pterini Shalla \& Bishop, 2007 (Lam07; Fig. 12-B), additional occurrence records were contributed within the expected ranges. The species Cimmerius reticulatus Jones, 1973 (Cer01; Fig. 12-C) was the first record for the family Ceratocumatidae to be found in the North Atlantic. Interesting new records of species in Icelandic waters such as Hemilamprops cf. diversus Hale, 1946 (Lam06; Fig. 12-D), previously only known from off South-eastern Australia, and Cumellopsis cf. puritani Calman, 1906 (Nan13), mostly recorded in the Mediterranean Sea, might either represent unexpected wide distribution ranges for these species or presence of morphologically closely related species, but new to science. 
436 In order to minimize the taxonomic knowledge gap, especially in ecoregion 2, the focus of this

437 study is on specimens collected within the regions 1, 2, 4 and 5, which represent all three water-

438 mass categories (North Atlantic, Subarctic, Arctic) and differed remarkably in their taxa

439 composition.

440 Representatives of the Arctic Ocean (ecoregion 1)

441 One representative specimen of the circumpolar species Diastylis spinulosa Heller, 1875 (Dia08;

442 Fig. 12-E) was detected from north of Spitzbergen. In congruence with the OBIS occurrence

443 records, ecoregion 1 was dominated by representatives of the families Diastylidae, Leuconidae

444 and Nannastacidae. The morphologically examined material from the Arctic Ocean included

445 only four species: Leptostylis cf. longimana (Dia16-B) dominated in specimen number, followed

446 by Campylaspis rubicunda (Nan08; Fig. 12-F), Campylaspis intermedia (Nan06; Fig. 13-A) and

447 one specimen of Leucon (Alytoleuco) pallidus (Leu05). Campylaspis intermedia is known to be

448 widely distributed in the whole Atlantic Ocean but was not recorded in the Arctic yet. Thus, the

449 occurrence records in the present study from north of Svalbard extend the previously assumed

450 distribution range significantly. Campylaspis rubicunda is known from the North Pacific, the

451 North Atlantic and the Arctic Oceans and Leptostylis longimana is widely distributed in the cold

452 areas of the Northern Atlantic. Nevertheless, none of the previously mentioned species is found

453 strictly in ecoregion 1, but rather widely distributed and occurring in other ecoregions.

454

455

456

457

458

459

460

461

462

463

464

465

466

467

468

469

470

471

\section{Representatives of East Greenland Sea (ecoregion 2)}

The most common species in ecoregion 2 was Diastylis polaris (Dia06), which was sampled at five IceAGE stations composed of NSDWw and NSDWc. This observation corresponds with the occurrence records found in OBIS, which also include the morphologically closely related Diastylis stygia G.O. Sars, 1871, both being described as true Arctic species. The species Leptostylis borealis (Dia15), originally described south of Franz-Josef-Land, was recorded for the first-time off Iceland. Most representatives of the family Leuconidae in the IceAGE material were sampled in ecoregion 2, north of the Iceland-Faroe-Ridge. This result suggested a restricted distribution range of sampled representatives of the family Leuconidae to colder and fresher water masses (e.g., APW, NSAIW and NSDW). The species Leucon (Leucon) profundus Hansen, 1920 (Leu11; Fig. 13-B) and Leucon (Alytoleucon) pallidus (Leu05) were the most common species of this family in the investigated material. Vassilenko (1989) and Gerken \& Watling (1999) described both with a circumpolar distribution range from the North Atlantic Ocean to the Canadian Arctic Ocean, but mostly found in cold-water stations (Watling \& Gerken, 2005). However, by our samples, new occurrence records of these species were added in the Norwegian Sea waters influenced by the North-Atlantic current, suggesting an extension of the distribution range for warmer waters of the previously assumed cold-water species.

Representatives of the North Atlantic and Norwegian Sea (ecoregion 4 and 5)

Peer] reviewing PDF | (2021:03:59368:1:2:NEW 8 Sep 2021) 
472 Ecoregion 4 was dominated in specimens by Hemilamprops cf. diversus (Lam07) and

473 Hemilamprops pterini (Lam08), which are taxa found predominantly in warmer waters, as well

474 as Campylaspis sp. 2 (Nan10; Fig. 13-C). In general, the genera Hemilamprops and Campylaspis

475 reached highest record numbers both in terms of taxa and specimen count. The widely

476 distributed boreal Atlantic species Hemilamprops cf. cristatus (Lam05-B) is recorded to occur in

477 high abundances within ecoregion 4 and 5, though it was also sampled at one station in the

478 Denmark strait. Specimens in ecoregion 4 were mostly sampled in deep-sea habitats, while

479 specimens in ecoregion 5 were mostly sampled in coastal and fjord habitats. Typical Atlantic

480 Ocean species of other families only recorded south of the GIS-Ridge in warmer waters were

481 Diastyloides atlanticus Reyss, 1974 (Dia10; Diastylidae; Fig. 13-D), Bathycuma brevirostre

482 Norman, 1879 (Bod01; Bodotriidae) and Cyclaspis longicaudata Sars, 1865 (Bod05;

483 Bodotriidae; Fig. 13-E), as well as Pseudocuma sp. 1 (Pse02), the only representative of the

484 Pseudocumatidae in the ICECU dataset. Cimmerius reticulatus (Cer01), expanding its

485 distribution northward from the Bay of Biscay, is the only representative of the Ceratocumatidae.

486 The specimens of Eudorella truncatula sampled in ecoregion 4 (Leu04-A/-B; Fig. S2-U) and

487 ecoregion 5 (Leu04-C) were all separated into distinct lineages, which was also observed in

488 Cyclapsis longicaudata from ecoregion 4 (Bod05-B) and ecoregion 5 (Bod05-A).

489

490

\section{Discussion}

491

492

\section{Combined species-delimitation approach - morphology and genetics}

493

494

495

496

497

498

499

500

501

502

503

504

505

506

507

508

509

510

As only a handful of studies applied molecular methods for species delimitation within cumaceans, the combined approach in this study highlights the high quality and overall congruence in most cases of morphological and genetic analyses. Even though delimiting species based solely on one mitochondrial marker like 16S rDNA has been questioned as there is no universal threshold for species delimitation (Meyer \& Paulay, 2005; Meier et al., 2006; Wiemers \& Fiedler, 2007; Schwentner et al., 2011; Collins \& Cruickshank, 2013), in our study a clear barcoding gap between 2 and $8 \%$ was observed among most inferred species, corresponding nicely with morphological taxonomic characters in the vast majority of cases. The $4 \%$ genetic distance observed between the geographically widely separated $(>3000 \mathrm{~km})$ Diastylis rathkei (Dia07) individuals cannot be easily interpreted as either intra- or interspecific and might hint at a recent and/or ongoing speciation event. Similar observations have been made previously for 16S rDNA of cumaceans and other peracarids like isopods (Brökeland \& Raupach, 2008; Held \& Wägele, 2005; Rehm 2007; Rehm et al., 2020; Riehl et al., 2018). Herein, intraspecific distances were usually below $1 \%$, though geographically widely distributed species featured up to 3 or $5 \%$, respectively. Conversely, interspecific distances exceeded 7\%. Also, here the higher intraspecific genetic distances of 5\% were tentatively suggested to represent potential cryptic species (Rehm, 2007). Based on these findings we suggest that the rare cases of conflict between morphological and genetic data represent cases of cryptic diversity or extensive morphological variability. 


\section{Examples of morphologically cryptic diversity}

512 The incongruence of $16 \mathrm{~S}$ sequence data revealing high genetic diversity within a species (or even

513 cryptic species) was observed in six cases (Table 4). This affects Hemilamprops cristatus

514 (Lam05, A-B), Eudorella truncatula (Leu04, A-C), Cyclaspis longicaudata (Bod05, A-B),

515 Leptostylis borealis (Dia15, A-B) and Leptostylis sp. 1 (Dia18, A-B; Fig. S2-L). The

516 intraspecific genetic distances observed within each of these taxa greatly exceeded those

517 commonly observed within species of Cumacea and other peracarids. We therefore conclude that

518 all of these cases indicate presence of morphologically cryptic species. Moreover, some of these

519 cryptic species were not even recovered as sister species, but widely separated (Fig. 2). Further

520 taxonomic studies will be needed to prove these cases.

521 In Cyclaspis longicaudata (Bod05, A-B), Eudorella truncatula (Leu04, A-C) and Leptostylis

522 borealis (Dia15, A-B) the respective cryptic species were geographically well separated and

523 usually occurred in different water masses. In the case of Hemilamprops cristatus (Lam05, A-B),

524 morphological re-examinations showed weak differences in the rostrum length and the serration

525 of the dorsal crest on the carapace (shorter rostrum and smaller, but more teeth in Lam05-A).

526 However, one specimen (ICE1-Lam018) sampled on the Greenland slope in Subarctic waters

527 and morphologically corresponding to Lam05-B, clustered genetically together with Lam05-A

528 from the Norwegian continental shelf.

529 Our cumacean examples do support the finding in other peracarid taxa (amphipods and isopods)

530 of either overestimations (Loerz et al., 2020) or underestimations of intraspecific divergence

531 (Brix et al., 2014b; Jennings et al., 2019; Paulus et al., 2021). This emphasizes that sampling

532 from a geographically limited portion of a species' range only risks missing relevant genetic

533 variation, which blurs an important line between species-level and population-level diversity.

534 Molecular species delimitation should, thus, include specimens sampled in the widest possible

535 distribution range of the examined taxon (Knox, 2012).

536 Examples of morphological variability and taxonomic incongruence

537 Specimens identified as Diastylis polaris (Dia06) and Diastylis stygia were identical in 16S.

538 Interestingly, Zimmer (1926) synonymized these species based on Ohlin's (1901) and Stebbing's

539 (1913) conclusion of their conspecifity. In 1980, Zimmer re-examined a specimen of D. stygia

540 collected by the Russian Sadko Expedition (Zimmer, 1943) and separated it again from $D$.

541 polaris as a valid species. Our study lays additional support for $D$. stygia being a synonym of $D$.

542 polaris. Similarly, after re-examination of Platysympus typicus (Lam14) sampled off East

543 Greenland and P. tricarinatus Hansen, 1920 from the Norwegian shelf, these two species names

544 are probably representing the same species. Gerken (2018) called the assumed differentiating

545 characters of more or less conspicuous folds on the carapace into doubt and suggested that less

546 prominent characters might be owed to juvenile stages. Therefore, $P$. tricarinatus is assumed to

547 be a synonym of P. typicus. Similarly, Leucon (Leucon) aff. nathorsti (Leu09) differed

Peer) reviewing PDF | (2021:03:59368:1:2:NEW 8 Sep 2021) 
548 morphologically from $L$. (L.) nathorsti (Leu08) by the presence of two dorsolateral teeth on the

549 frontal lobe of the carapace and a more acute rostrum and, thus, identified as a possible separate

550 species. However, in this $16 \mathrm{~S}$ analyses these two morphotypes proved to be identical, suggesting

551 the presence of a single, morphologically variable species. As Leu08-specimens were sampled

552 on the Norwegian continental shelf in North Atlantic waters and Leu09 was collected off

553 Svalbard in Subarctic waters, an ecologically-driven morphological population variation might

554 be implied.

555 Further, we found that the two morphologically almost indistinguishable species Leptostylis

556 longimana (Dia16-B) and L. ampullacea (Dia14) grouped into a large unresolved clade forming

557 a "Leptostylis longimana/ampullacea" species complex. Species in the genus Leptostylis are

558 rather difficult to distinguish as there is a certain degree of phenotypic plasticity tied to sex and

559 growth stages, and some morphological distinctions are quite subjective, such as 'clumsier' body

560 form of L. ampullacea compared to L. longimana (Sars GO, 1900). A second "Leptostylis

561 longimana"-clade was retrieved, based on specimens from coastal Norway, genetically well

562 separated from the Iceland/Arctic " $L$. longimana/ampullacea"-clade by $26-27 \% p$-distance.

563 Based on the present data, the Iceland/Arctic specimens should be referred to L. ampullacea,

564 originally described from Kullaberg (off Sweden). This further implies that the "true" $L$.

565 longimana, originally described from the Oslofjord, a more coastal and/or southern distribution.

566 Further studies including additional specimens and gene markers, as well as museum type

567 material will be necessary to resolve the taxonomy in more detail.

\section{Biogeographic integration}

569

570

571

572

573

574

575

576

577

578

579

580

581

582

583

584

\section{Data-mining implications}

This study contributed with the ICECU dataset first occurrence records of 18 species representing five families within the investigated ecoregions (Fig. 8). Additionally, about $25 \%$ of morphologically determined taxa could not be assigned to species level, which might either constitute known species from originally other regions or new species to science. The extension of distribution ranges of ecoregional representative species clearly shows our knowledge gaps on estimated distribution patterns of cumaceans. By monitoring the impact of a changing climate on species distributions based on time series of the first occurrences of this species, the benefits of publicly accessible distribution data of marine animals on platforms such as OBIS are undeniable. The linkage to WoRMS ensures verified taxonomic name information following the Darwin Core standard and connection to other sources (Costello, 2007; Wieczorek et al., 2012). Still, the determination of species demands knowledge of taxonomy, ecology, and morphological characters of the investigated taxon. Especially molecular species delimitation depends on prior morphological identification and database confidence. The importance of such reliable species name assignments was especially observed in the genus Leptostylis, in which hidden diversity was found when integrating genetic data. Thus, caution should be taken when using public

Peer] reviewing PDF | (2021:03:59368:1:2:NEW 8 Sep 2021) 
585

586

587

588

589

590

591

592

593

594

595

596

597

598

599

600

601

602

603

604

605

606

607

608

609

610

611

612

613

614

615

616

617

618

619

620

621

distribution databases due to their restricted possibilities to present hidden diversity. This study showed that species identifications of a large dataset based only on morphological delimitation may underestimate true diversity. For example, in the case of the species Hemilamprops cristatus and Eudorella truncatula, which are assumed to be a widely distributed species in the boreal Arctic as well as in the North American basin (Watling, 2009), genetic analyses revealed either a cryptic speciation due to geographical separation and different water-mass conditions or species from distinct populations with separated geographical origins.

\section{Are ecoregions reflected in species distribution?}

The results of this study support the suggestion of Hansen (1920) and Watling \& Gerken (2005) that water-mass characteristics are an important controlling variable for cumacean species occurrences. The community composition was observed to change from warm-water dominating families in ecoregion 4 south of the GIS-Ridge (Lampropidae, Bodotriidae, Nannastacidae) to families dominating in colder and less saline Subarctic and Arctic water masses found in ecoregion 1 and 2 (Diastylidae, Leuconidae; Fig. 9).

Closer investigation of cumacean distributions on species level revealed that most species occurred in multiple ecologically similar ecoregions (Fig. 10; Table 5). Even though typical ecoregion-specific representatives could be determined, in many cases these also occurred in other ecoregions. This pattern was also corroborated by the genetic data. For example, Vassilenko (2002) categorized the species Campylaspis globosa (Nan04) and Hemilamprops uniplicatus G.O. Sars, 1872 (Lam11) as widely distributed Arcto-Atlantic bathyal species of Atlantic origin. This study supported the preceding assumption, as specimens inhabiting Arctic and Subarctic waters in the Denmark Strait (ecoregion 2) and Atlantic waters on the Norwegian continental shelf (ecoregion $4 \& 5$ ) were morphologically and genetically identical within the species (Fig. S2-Q; Fig. S2- $\alpha$ ). The same case was observed in Platysympus typicus (Lam13) and Diastylis polaris (Dia06) from Atlantic to Arctic water influenced ecoregions (1,2,4,5; Fig. 11-C; Fig. 11-E).

Some species revealed hidden diversity reflected by patchy distribution patterns within ecoregions. Cyclaspis longicaudata Bod05-B was sampled in the Iceland Basin (ecoregion 4) and was genetically differentiated and geographically separated by the GIS-Ridge to Bod05-A from the Norwegian continental shelf (ecoregion 5; Fig. 13-E). A similar case was observed between the species Hemilamprops cristatus Lam05-B from a deep Iceland Basin station (2500 m) and Lam05-A, which was sampled close to the type locality from Skagerrak (700 m depth; Fig. 11-F). As this species is reported as a widely distributed boreal Atlantic species, cryptic speciation might be considered due to the geographical separation by the GIS-Ridge. It would seem that $H$. cristatus in the Iceland basin might be a hidden, putative species new to science. Simultaneously, the Leptostylis longimana/ampullacea complex Dia14/-16-B from cold-water masses (NSDWw, APW, APW/NSAIW) was revealed to be widely distributed from Iceland to 
622 Arctic regions (ecoregions 1 and 2) over a distance of more than $2500 \mathrm{~km}$. Dia16-A, though, was 623 revealed to be a distinct genetically differentiated population in ecoregion 4. Earlier records of 624 this species complex are from the same distribution area, and described as a predominantly 625 bathyal Atlantic, boreal-Arctic species (Jones, 1976; Vassilenko, 1989). Watling \& Gerken 626 (2005) observed L. longimana to be present over a wide temperature range. Another example in 627 ecoregion 2 for potentially disrupted gene flow between populations by geographical barriers is 628 the species Leptostylis borealis Dia15-A from the East Greenland shelf and Dia15-B from East 629 Iceland Norwegian Sea, separated by the Denmark Strait (Fig. 12-A). In contrast, Leucon (A.) pallidus (Leu05) sampled at these stations showed no genetic differentiation between specimens, despite the Denmark Strait as a potential barrier. For the investigation of distinct cumacean distribution patterns as proposed by Watling \& Gerken (2005), a larger sample size is needed as many morpho- and genospecies were represented as singletons or were sampled in higher numbers, but at solely one station.

\section{Conclusions}

637

This study confirmed the advantage of a combined approach of traditional morphological and modern molecular techniques to delimit cumacean species and uncover hidden diversity, compared to delimitations based solely on one method. Some species may need more taxonomic attention and re-evaluation. We have shown examples of underestimated diversity as well as overestimated diversity. However, the advantage of molecular investigations for testing important questions of species diversity correlates significantly with prior species identifications and emphasizes the importance of a robust basis of taxonomic knowledge and morphological examination.

646 For example, in ecoregion 2, 98\% of the specimens could only be determined to order level. 647 When the resolution of identification only gets to order level, the species occurrence data is influenced as the species level information is not shown in public databases (for example). Thus, with more species level identifications in ecoregion 2, it is a high likelihood to find more species new to science or even more ecoregion-representative species. While this ecoregion was characterized by five representative species, ecoregion 4 revealed high species diversity with 45 representative species correlating with the highest sampling effort of all investigated regions. As for other peracarid groups, the GIS-Ridge plays an important role as a geographical barrier and separates ecoregion-specific cumacean communities between the North Atlantic Ocean in the south and the Subarctic seas in the north. Although the biogeographic results of this study furthermore support the assumption of earlier studies that water-mass characteristics are important controlling variables for cumacean species occurrences, this remains a hypothesis unless a more detailed ecological observation of factors shaping cumacean distribution with statistical analyses including not only water masses, but further abiotic factors (e.g. depth, sedimentary characteristics, potential geographical barriers) is undertaken. 
662

663

664

665

666

667

668

669

670

671

672

673

674

675

676

677

678

679

680

681

682

683

684

685

686

687

688

689

690

691

692

693

694

695

696

697

698

699

\section{Acknowledgements}

Firstly, we would like to emphasize that the base of this study is formed by excellent international collaboration, fruitful discussions, and trust-based exchange of experience and knowledge. It would not have been possible without team- and networking, starting with those, who invest many days to sample at sea, preserve, catalogue and sort benthic samples for further analyses. We owe an immense debt to Karen Jeskulke, Nicole Gatzemeier, Antje Fischer, Sven Hoffmann and the whole team of DZMB HH for the technical support at all levels. We warmly thank Kathrin Philipps-Bussau, Petra Wagner, Nancy Mercado Salas and Alexandra Kerbl for maintenance of the CeNak collection material. Many thanks to Simon Bober, Johanna Bober, Mariam Dunker and Oliver Hawlitschek for the help on laboratory issues. Our sincere thanks go to the Captains and Crew of RV Meteor and RV Polarstern during M85/3 (IceAGE) and PS106/1 (PASCAL). Big thanks to Team 'SIEMO' for their help and efficient work at sea. Special thanks go to Sarah Gerken and Ute Mühlenhardt-Siegel for taxonomical expertise and advice. We are grateful to Louise Lindblom for guidance and assistance in the Biodiversity laboratory at University of Bergen.

\section{References}

Bouckaert R, Vaughan TG, Barido-Sottani J, Duchêne S, Fourment M, Gavryushkina A, Heled J, Jones G, Kühnert D, De Maio N, Matschiner M. 2019. BEAST 2.5: An advanced software platform for Bayesian evolutionary analysis. PLoS computational biology, 15(4). DOI: 10.1371/journal.pcbi.1006650.

Błażewicz-Paszkowycz M, Siciński J. 2014. Diversity and distribution of Tanaidacea (Crustacea) along the Victoria Land Transect (Ross Sea, Southern Ocean). Polar biology, 37(4):519-529.

Bluhm BA, Ambrose WG, Bergmann M, Clough LM, Gebruk AV, Hasemann C, Iken K, Klages M, MacDonald IR, Renaud PE, Schewe I. 2011. Diversity of the arctic deep-sea benthos. Marine Biodiversity, 41(1):87-107.

Brandt A. 1997. Biodiversity of peracarid crustaceans (Malacostraca) from the shelf down to the deep Arctic Ocean. Biodiversity \& Conservation, 6(11):1533-1556.

Brandt A, Elsner N, Brenke N, Golovan O, Malyutina MV, Riehl T, Schwabe E, Würzberg L. 2013. Epifauna of the Sea of Japan collected via a new epibenthic sledge equipped with camera and environmental sensor systems. Deep Sea Research Part II: Topical Studies in Oceanography, 86:43-55.

Brattegard T, Fosså JH. 1991. Replicability of an epibenthic sampler. Journal of the Marine Biological Association of the United Kingdom, 71(1):153-166.

Brenke N. 2005. An epibenthic sledge for operations on marine soft bottom and bedrock. Marine Technology Society Journal, 39(2):10-21. 
700 Brix S, Svavarsson J. 2010. Distribution and diversity of desmosomatid and nannoniscid isopods 701 (Crustacea) on the Greenland-Iceland-Faeroe Ridge. Polar Biology, 33(4): 515-530. DOI:

702 10.1007/s00300-009-0729-8.

703 Brix S, Bauernfeind W, Brenke N, Błażewicz-Paszkowycz M, Borges V, Buldt K, Cannon JT, 704 Díaz-Agras G, Fiege D, Fiorentino D, Haraldsdóttir S. 2012. Overflow, circulation and 705 biodiversity-Cruise No. M85/3-August 27-September 28, 2011-Reykjavik (Iceland)-Cuxhaven 706 (Germany). Meteor-Berichte M85/3, 41. DOI: 10.2312/cr_m85_3.

707 Brix S, Meissner K, Stransky B, Halanych KM, Jennings RM, Kocot KM, Svavarsson J. 2014 a. 708

709 Preface: The IceAGE project-a follow up of BIOICE. Polish Polar Research, 35(2):141-150. Brix S, Svavarsson J, Leese F. 2014b. A multi-gene analysis reveals multiple highly divergent lineages of the isopod Chelator insignis (Hansen, 1916) south of Iceland. Polish Polar Research, 35(2):225-242.

712 Brix S, Loerz AN, Jażdżewska AM, Hughes L, Tandberg AHS, Pabis K, Stransky B, Krapp-

713 Schickel T, Sorbe JC. 2018a. Amphipod family distributions around Iceland. ZooKeys, 731:41714 53. DOI: 10.3897/zookeys.731.19854.

715 Brix S, Stransky B, Malyutina M, Pabis K, Svavarsson J, Riehl T. 2018b. Distributional patterns 716 of isopods (Crustacea) in Icelandic and adjacent waters. Marine Biodiversity, 48(2):783-811.

717 Brix S, Devey CW. 2019. Stationlist of the IceAGE project (Icelandic marine Animals: Genetics 718 and Ecology) expeditions. Marine Data Archive. DOI: 10.14284/349.

719 Brökeland W, Raupach MJ. 2008. A species complex within the isopod genus Haploniscus 720 (Crustacea: Malacostraca: Peracarida) from the Southern Ocean deep sea: a morphological and 721 molecular approach. Zoological Journal of the Linnean Society, 152(4):655-706.

722 Collins RA, Cruickshank RH. 2013. The seven deadly sins of DNA barcoding. Molecular 723 ecology resources, 13(6):969-975.

724 Conlan K, Aitken A, Hendrycks E, McClelland C, Melling H. 2008. Distribution patterns of 725 Canadian Beaufort Shelf macrobenthos. Journal of Marine Systems, 74:864-886.

726 Costello MJ, Stocks K, Zhang Y, Grassle JF, Fautin DG. 2007. About the Ocean Biogeographic 727 Information System. Available at https://obis.org/ (accessed 19 September 2019).

728 Curtis MA. 1975. The marine benthos of arctic and sub-arctic continental shelves. Polar Record, 729 17(111):595-626.

730 Dunbar MJ. 1951. Eastern Arctic waters. Journal of the Fisheries Research Board Bulletin, 88:1731131.

732 Dunbar MJ. 1972. The nature and definition of the marine subarctic, with a note on the sea-life 733 area of the Atlantic salmon. Transactions of the Royal Society of Canada, 10:249-57.

734 Foxon GEH. 1936. Notes on the natural history of certain sand-dwelling Cumacea. Journal of 735 Natural History, 17(99):377-393.

736 Gage JD, Lambshead PJD, Bishop JDD, Stuart CT, Jones NS. 2004. Large-scale biodiversity 737 pattern of Cumacea (Peracarida: Crustacea) in the deep Atlantic. Marine Ecology Progress 738 Series, 277:181-196. 
739 Gerken S, Watling L. 1999. Cumacea (Crustacea) of the Faroe Islands Region. Frodskaparrit, $740 \quad 47: 199-227$.

741 Gerken S. 2018. The Lampropidae (Crustacea: Cumacea) of the World. Zootaxa, 4428(1):1-192.

742 Hall TA. 1999. BioEdit: a user-friendly biological sequence alignment editor and analysis

743 program for Windows 95/98/NT. Nucleic acids symposium series, 41:95-98.

744 Hansen HJ. 1920. The Order Cumacea. In: Crustacea Malacostraca. Danish Ingolf-Expedition, 745 4:3(6):1-86.

746 Hansen B, Osterhus S. 2000. North Atlantic-Nordic Seas exchanges. Progress in Oceanography, 747 45:109-208. DOI: 10.1016/S0079-6611(99)00052-X.

748 Haye PA. 2002. Systematics of the Cumacea (Crustacea). Doctoral dissertation, University of 749 Maine.

750 Haye PA, Kornfield I, Watling L. 2004. Molecular insights into Cumacean family relationships 751 (Crustacea, Cumacea). Molecular Phylogenetics and Evolution, 30(3):798-809.

752 Held C, Wägele JW. 2005. Cryptic speciation in the giant Antarctic isopod Glyptonotus 753 antarcticus (Isopoda, Valvifera, Chaetiliidae). Scientia marina, 69(2):175-181.

754 Hessler RR, Jumars PA. 1974. Abyssal community analysis from replicate box cores in the 755 central North Pacific. Deep-Sea Research, 21:185- 209.

756 Jennings RM, Golovan O, Brix S. 2019. Integrative species delimitation of desmosomatid and

757 nannoniscid isopods from the Kuril-Kamchatka trench, with description of a hadal species.

758 Progress in Oceanography. DOI: 10.1016/j.pocean.2019.102236.

759 Jones NS, Sanders HL. 1972. Distribution of Cumacea in the deep Atlantic. Deep-Sea Research, 760 19:737-745.

761 Jones NS. 1976. British Cumaceans. Synopses of the British Fauna (new series). Linnaean

762 Society of London, 7:1-62.

763 Katoh K. 2002. MAFFT: A novel method for rapid multiple sequence alignment based on fast

764 Fourier transform. Nucleic Acids Research, 30:3059-3066. DOI: 10.1093/nar/gkf436.

765 Katoh K, Standley DM. 2013. MAFFT multiple sequence alignment software version 7:

766 improvements in performance and usability. Molecular biology and evolution, 30(4):772-780.

767 Kearse M, Moir R, Wilson A, Stones-Havas S, Cheung M, Sturrock S, Buxton S, Cooper A,

768 Markowitz S, Duran C, Thierer T. 2012. Geneious Basic: an integrated and extendable desktop

769 software platform for the organization and analysis of sequence data. Bioinformatics,

770 28(12):1647-1649.

771 Knox MA. 2012. Diversity of New Zealand Deep-sea Amphipoda. Doctoral dissertation,

772 University of Waikato.

773 Kumar S, Stecher G, Li M, Knyaz C, Tamura K. 2018. MEGA X: molecular evolutionary

774 genetics analysis across computing platforms. Molecular biology and evolution, 35(6):1547-

7751549.

776 Lanave C, Preparata G, Sacone C, Serio G. 1984. A new method for calculating evolutionary

777 substitution rates. Journal of molecular evolution, 20(1):86-93. 
778 Loerz AN, Brix S, Jażdżewska AM, Hughes LE. 2020. Diversity and distribution of North 779 Atlantic Lepechinellidae (Amphipoda: Crustacea). Zoological Journal of the Linnean Society, 780 190(4):1095-1122.

781 Loerz A-N, Kaiser S, Oldeland J, Stolter C, Kürzel K, Brix S. 2021. Biogeography, diversity and 782 environmental relationships of shelf and deep-sea benthic Amphipoda around Iceland. PeerJ.

783 DOI: 10.7717 peerj.11898

784 Macke A, Flores H. 2018. The Expeditions PS106/1 and 2 of the Research Vessel

785 POLARSTERN to the Arctic Ocean in 2017. Reports on polar and marine research,

786 Bremerhaven, Alfred Wegener Institute for Polar and Marine Research, 719. DOI:

787 10.2312/BzPM_0719_2018.

788 Malmberg S-A, Valdimarsson H. 2003. Hydrographic conditions in Icelandic waters, 1990-

789 1999. ICES Marine Science Symposia, 219:50-60.

790 Miller MA, Pfeiffer W, Schwartz T. 2010. Creating the CIPRES Science Gateway for inference

791 of large phylogenetic trees. Proceedings of the Gateway Computing Environments Workshop

792 (GCE), New Orleans, LA, 1-8.

793 Meier R, Shiyang K, Vaidya G, Ng PK. 2006. DNA barcoding and taxonomy in Diptera: a tale 794 of high intraspecific variability and low identification success. Systematic biology, 55(5):715795728.

796 Meißner K, Brenke N, Svavarsson J. 2014. Benthic habitats around Iceland investigated during 797 the IceAGE expedition. Polish Polar Research, 35(2):177-202. DOI: 10.2478/popore-2014-0016. 798 Meißner K, Brix S, Halanych KM, Jażdżewska AM. 2018. Preface - biodiversity of Icelandic 799 waters. Marine Biodiversity, 48:715-718. DOI: 10.1007/s12526-018-0884-7.

800 Meyer CP, Paulay G. 2005. DNA barcoding: error rates based on comprehensive sampling. 801 PLoS biology, 3(12):e422.

802 Mironov AN, Dilman AB, Krylova EM. 2013. Global distribution patterns of genera occurring in 803 the Arctic Ocean deeper 2000 m. Invertebrate Zoology, 10(1):167-194.

804 Nørrevang A, Brattegard T, Josefson AB, Sneli JA, Tendal OS. 1994. List of BIOFAR stations. 805 Sarsia 79(3):165-180.

806 Nylander JA, Ronquist F, Huelsenbeck JP, Nieves-Aldrey J. 2004. Bayesian phylogenetic 807 analysis of combined data. Systematic biology, 53(1):47-67.

808 OBIS. 2019. Ocean Biodiversity Information System. Intergovernmental Oceanographic

809 Commission of UNESCO. Available at www.obis.org (accessed 19 September 2019).

810 Ohlin A. 1901. Arctic Crustacea collected during the Swedish Arctic Expeditions 1898 and 1899

811 under the direction of Professor A.G. Nathorst. I. Leptostraca, Isopoda, Cumacea. Bihang till

812 Svenska Vetenskaps-Akademiens Handlingar, 26,4,12:1-54.

813 Omarsdottir S, Einarsdottir E, Ögmundsdottir HM, Freysdottir J, Olafsdottir ES, Molinski TF, 814 Svavarsson J. 2013. Biodiversity of benthic invertebrates and bioprospecting in Icelandic waters. 815 Phytochemistry reviews, 12(3):517-529. 
816 Ostmann A, Schnurr S, Arbizu PM. 2014. Marine environment around Iceland: hydrography, 817 sediments and first predictive models of Icelandic deep-sea sediment characteristics. Polish Polar 818 Research, 151-176.

819 Palumbi S, Martin A, Romano S. 1991. 16s RNA primers. The simple fool's guide to PCR, 820 version 2. Honolulu: University of Hawaii Press, 28.

821 Paulus E, Brix S, Siebert A, Martínez Arbizu P, Rossel S, Peters J, Svavarsson J, Schwentner M.

822

823

824

825

826

827

828

829

830

831

832

833

834

835

836

837

838

839

840

841

842

843

844

845

846

847

848

849

850

851

852

853

854

855 2021. Recent speciation and hybridization in Icelandic deep-sea isopods: an integrative approach using genomics and proteomics. Authorea. DOI: 10.22541/au.161773761.10234925/v1 Petrescu I, Heard RW, Vargas R, Breedy O. 2009. Cumaceans. In: Wehrtmann IS, Cortés J, ed. Marine Biodiversity of Costa Rica, Central America. Monographiae Biologicae. Berlin: Springer \& Business Media BV, 86:237-244. DOI: 10.1007/978-1-4020-8278-8_21.

Piepenburg D, Archambault P, Ambrose WG, Blanchard AL, Bluhm BA, Carroll ML, Conlan KE, Cusson M, Feder HM, Grebmeier JM, Jewett SC. 2011. Towards a pan-Arctic inventory of the species diversity of the macro-and megabenthic fauna of the Arctic shelf seas. Marine Biodiversity, 41(1):51-70.

Pons J, Barraclough TG, Gomez-Zurita J, Cardoso A, Duran DP, Hazell S, Kamoun S, Sumlin WD, Vogler AP. 2006. Sequence-based species delimitation for the DNA taxonomy of undescribed insects. Systematic biology, 55(4):595-609.

Puillandre N, Lambert A, Brouillet S, Achaz G. 2012. ABGD, Automatic Barcode Gap Discovery for primary species delimitation. Molecular ecology, 21(8):1864-1877. Available at https://bioinfo.mnhn.fr/abi/public/abgd/abgdweb.html (accessed 20 December 2019).

Rambaut A. 2018a. FigTree version 1.4.4. Computer program and documentation distributed by the author. Available at http://tree.bio.ed.ac.uk/software/figtree/ (accessed 15 December 2019). Rambaut A, Drummond AJ, Xie D, Baele G, Suchard MA. 2018b. Posterior summarisation in Bayesian phylogenetics using Tracer 1.7. Systematic Biology, 67(5):901-904. DOI:

10.1093/sysbio/syy032.

Rehm P. 2007. Cumacea (Crustacea; Peracarida) of the Antarctic shelf-diversity, biogeography, and phylogeny. Doctoral dissertation, University of Bremen.

Rehm P, Thatje S, Leese F, Held C. 2020. Phylogenetic relationship within Cumacea (Crustacea: Peracarida) and genetic variability of two Antarctic species of the family Leuconidae. Scientia Marina, 84(4):385-392. DOI: 10.3989/scimar.05053.17A.

Rex MA. 1981. Community structure in the deep-sea benthos. Annual Review of Ecology and Systematics, 12(1):331-353.

Riehl T, Brenke N, Brix S, Driskell A, Kaiser S, Brandt A. 2014. Field and laboratory methods for DNA studies on deep-sea isopod crustaceans. Polish Polar Research, 35(2):203-224.

Riehl T, Lins L, Brandt A. 2018. The effects of depth, distance, and the Mid-Atlantic Ridge on genetic differentiation of abyssal and hadal isopods (Macrostylidae). Deep Sea Research Part II: Topical Studies in Oceanography, 148:74-90.

Rodriguez FJLOJ, Oliver JL, Marin A, Medina JR. 1990. The general stochastic model of nucleotide substitution. Journal of theoretical biology, 142(4):485-501. 
856 Ronquist F, Teslenko M, Van Der Mark P, Ayres DL, Darling A, Höhna S, Larget B, Liu L, 857 Suchard MA, Huelsenbeck JP. 2012. MrBayes 3.2: efficient Bayesian phylogenetic inference 858 and model choice across a large model space. Systematic biology, 61(3):539-542.

859 Rothlisberg P, Pearcy WG. 1976. An epibenthic sampler used to study the ontogeny of vertical 860 migration of Pandalus dordani (Decapoda, Caridea). Fishery Bulletin, National Oceanic and 861 Atmospheric Administration of the United States, 74:994-997.

862 Sars GO. 1900. An account of the Crustacea of Norway, Ill. Cumacea. Bergen Museum, Bergen, 863 Norway, 3:1-115.

864 Schlichtholz P, Houssais MN. 2002. An overview of the $y-S$ correlations in Fram Strait based on 865 the MIZEX 84 data. Oceanologia, 44:243-272.

866 Schnurr S, Brandt A, Brix S, Fiorentino D, Malyutina M, Svavarsson J. 2014. Composition and

867 distribution of selected munnopsid genera (Crustacea, Isopoda, Asellota) in Icelandic waters.

868 Deep Sea Research Part I: Oceanographic Research Papers, 84:142-155.

869 Schwentner M, Timms BV, Richter S. 2011. An integrative approach to species delineation

870 incorporating different species concepts: a case study of Limnadopsis (Branchiopoda:

871 Spinicaudata). Biological Journal of the Linnean Society, 104(3):575-599.

872 Silva CDLA. 2016. Taxonomy, systematics, morphological and molecular phylogeny of the 873 order Tanaidacea (Crustacea: Peracarida), from the Antarctic, Atlantic and Pacific Oceans.

874 Doctoral dissertation, University of Porto.

875 Spalding MD, Fox HE, Allen GR, Davidson N, Ferdaña ZA, Finlayson MAX, Halpern BS, Jorge

876 MA, Lombana AL, Lourie SA, Martin KD. 2007. Marine ecoregions of the world: a

877 bioregionalization of coastal and shelf areas. Bioscience, 57:573-583.

878 Stebbing TRR. 1913. Cumacea (Sympoda). In: Das Tierreich. Berlin: R. Fiedlander and Son, $879 \quad 39: 1-210$

880 Stransky B, Svavarsson J. 2010. Diversity and species composition of peracarids (Crustacea:

881 Malacostraca) on the South Greenland Shelf: spatial and temporal variation. Polar Biology,

$88233: 125-139$.

883 Thorsnes T. 2009. MAREANO - an introduction. Norwegian Journal of Geology, 89(3).

884 Uhlir C, Meland K, Glenner H, Brandt A, Brix S. 2021. North Atlantic and Arctic Cumacea

885 sampled during the IceAGE (2011) and PASCAL (2017) project. Marine Data Archive.

886 Vassilenko SV. 1989. Arctic Ocean Cumacea. In: Herman Y, ed. The Arctic Seas - Climatology,

887 Oceanography, Geology, and Biology, 431-444.

888 Vassilenko SV, Brandt A. 1996. Composition and biogeographic structure of the cumacean

889 fauna of the Northeast Water Polynya, Greenland (Crustacea, Peracarida, Cumacea). Arthropoda 890 Selecta, 5:27-38.

891 Vassilenko SV. 2002. Cumaceans as indicators of Atlantic Waters over the continental slope of 892 the Arctic Ocean. Russian Journal of Marine Biology, 28(1):1-6.

893 Vihtakari M. 2019. PlotSvalbard: PlotSvalbard - Plot research data from Svalbard on maps. R 894 package version 0.8.5. Available at https://github.com/MikkoVihtakari/PlotSvalbard (accessed 89511 November 2019). 
896 Watling L, Gerken S. 2005. The Cumacea of the Faroe Islands region: water mass relationships 897 and North Atlantic biogeography. BIOFAR Proceedings, 137-149.

898 Watling L. 2009. Biogeographic provinces in the Atlantic deep sea determined from cumacean 899 distribution patterns. Deep Sea Research Part II: Topical Studies in Oceanography, 56(19900 20):1747-1753.

901 Watling L, Gerken S. 2019. World Cumacea Database. Accessed at 902 http://www.marinespecies.org/cumacea (accessed 12 November 2019). DOI:10.14284/354.

903 Weisshappel J, Svavarsson J. 1998. Benthic amphipods (Crustacea: Malacostraca) in Icelandic 904 waters: diversity in relation to faunal patterns from shallow to intermediate deep Arctic and 905 North Atlantic Oceans. Marine Biology, 131:133-143. DOI: 10.1007/s002270050304.

906 Weisshappel JB. 2000. Distribution and diversity of the hyperbenthic amphipod family Eusiridae

907 in the different seas around the Greenland-Iceland-Faeroe-Ridge. Sarsia, 85:227-236. DOI:

$90810.1080 / 00364827.2000 .10414575$.

909 Weisshappel JB. 2001. Distribution and diversity of the hyperbenthic amphipod family

910 Calliopiidae in the different seas around the Greenland-Iceland-Faeroe-Ridge. Sarsia, 86:143-

911 151. DOI: 10.1080/00364827.2001.10420469.

912 Westheide W, Rieger R, ed. 1996. Spezielle Zoologie, Teil 1: Einzeller und wirbellose Tiere.

913 Stuttgart: Gustav Fischer, 582-600.

914 Wieczorek J, Bloom D, Guralnick R, Blum S, Döring M, Giovanni R, Robertson T, Vieglais D.

915 2012. Darwin Core: an evolving community-developed biodiversity data standard. PloS one,

916 7(1):e29715.

917 Wiemers M, Fiedler K. 2007. Does the DNA barcoding gap exist? A case study in blue

918 butterflies (Lepidoptera: Lycaenidae). Frontiers in Zoology, 4:8.

919 Wilson GD, Hessler RR. 1987. Speciation in the deep sea. Annual Review of Ecology and

920 Systematics, 18(1):185-207.

921 WoRMS Editorial Board. 2019. World Register of Marine Species. Available from

922 http://www.marinespecies.org at VLIZ (accessed 23 November 2019). DOI:10.14284/170.

923 Xiong B, Kocher TD. 1991. Comparison of mitochondrial DNA sequences of seven

924 morphospecies of black flies (Diptera: Simuliidae). Genome, 34(2):306-311.

925 Zimmer C. 1926. Northern and Arctic invertebrates in the collection of the Swedish State

926 Museum, X. Cumaceen. Kongliga Svenska Vetenskaps-Akademiens Förhandlingar, 3(2):1-88.

927 Zimmer C. 1943. Über neue und weniger bekannte Cumaceen. Zoolgischer Anzeiger, 141(7-

928 8):148-167.

929 Zimmer C. 1980. Cumaceans of the American Atlantic boreal coast region (Crustacea:

930 Peracarida). Bowman IE, Watling L, ed. Smithsonian contributions to zoology, 302:1-29.

931

932 


\section{Figure 1}

Station sites of investigated cumacean specimens sampled during IceAGE and PASCAL expedition.

(A) All investigated station sites of cruise leg M85/3 (IceAGE) and PS106/1 (PASCAL) with information on the study area, deployed gear types and assigned water masses after Schlichtholz \& Houssais (2002), Hansen \& Østerhus (2000), Brix \& Svavarsson (2010) and Ostmann et al. (2014). (B) Drifting area of cruise leg PS106/1 marking the seven Box corer stations (BC; yellow stars) and the one Epibenthic sled station (EBS; green star; Macke \& Flores, 2018). 


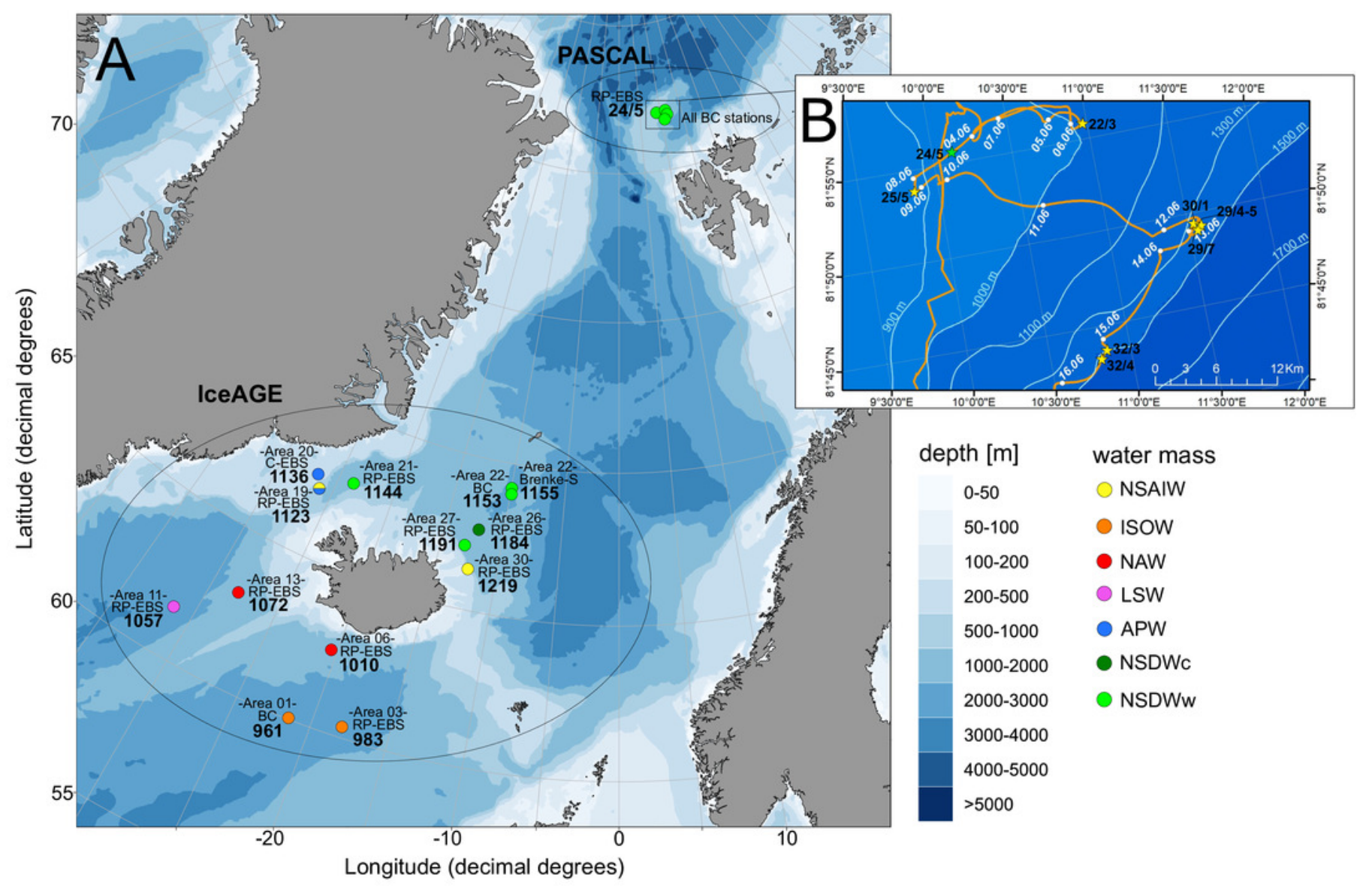




\section{Figure 2}

DATASET I - Phylogenetic analyses based on the 16S rRNA gene region of Cumacea from Northern Atlantic to Arctic waters.

Included in the Bayesian analysis were 80 sequences of all morphologically determined cumacean species, 67 sequences published on GenBank of which 51 sequences are originating from North Atlantic cumaceans currently studied at the University Bergen as well as 16 from outside the study area and 8 other peracarid outgroup sequences (Isopoda, Amphipoda, Tanaidacea). The branch labels indicate posterior probability scores in percent decimal values ( $1=$ absolute support in all calculated trees). The scale bar at the bottom of the tree shows nucleotide substitutions per site of sequence. Colours are representing family taxa, which were split into dataset II-V for subsequent genetic distance analyses. Genetic lineages are separated by assigned letters $A / B / C$. 


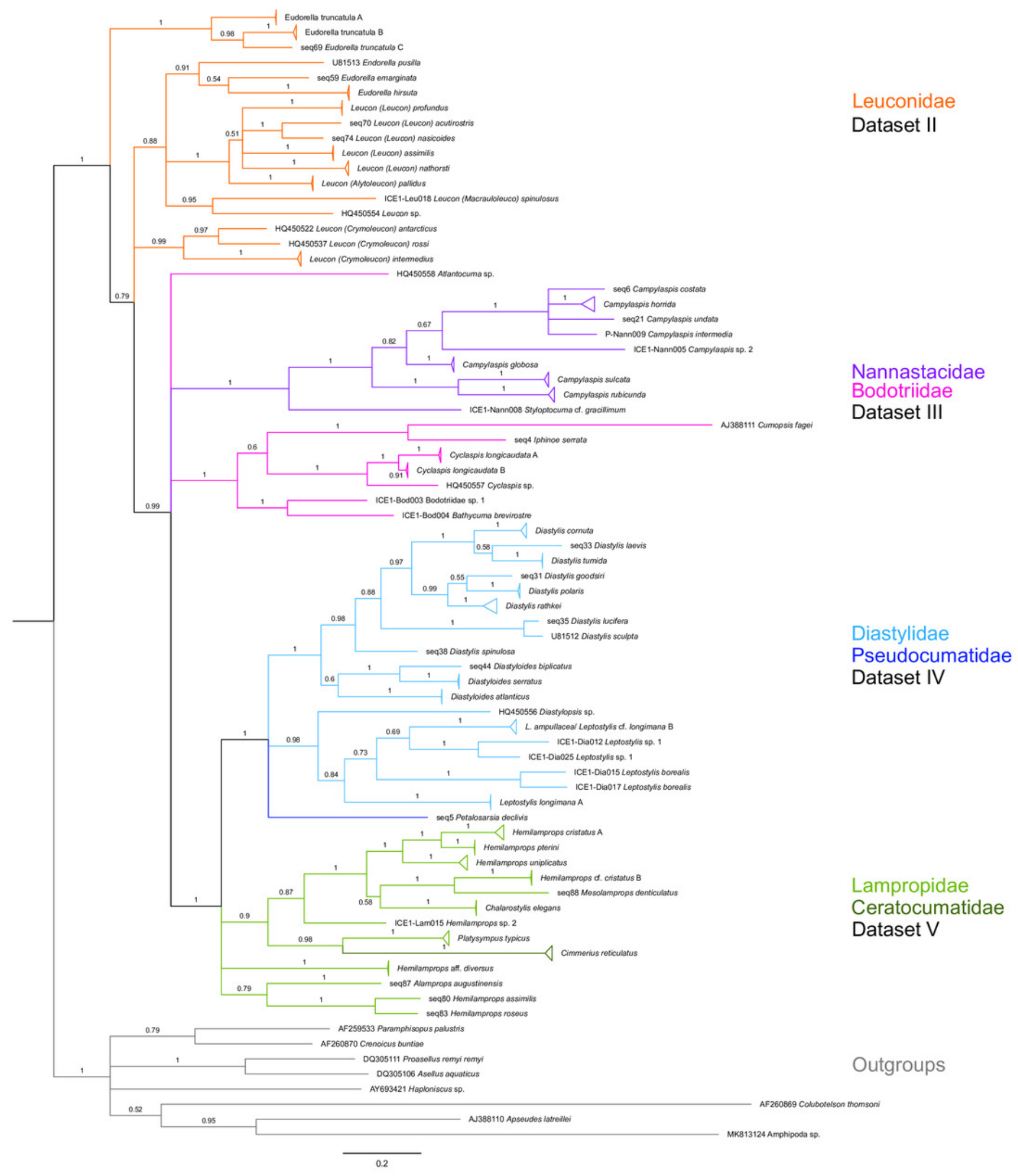


Figure 3

DATASET II - Phylogenetic relationships inferred by Bayesian analysis of the Leuconidae.

The branch labels indicate posterior probability scores. The scale bar at the bottom of the tree shows nucleotide substitutions per site of sequence. Sequences in parentheses were excluded from genetic distance analyses due to insufficient sequence length. Vertical bars indicate the species delimited based on morphology, ABGD and GMYC with colors representing genera. Genetic lineages are separated by assigned letters $A / B / C$.
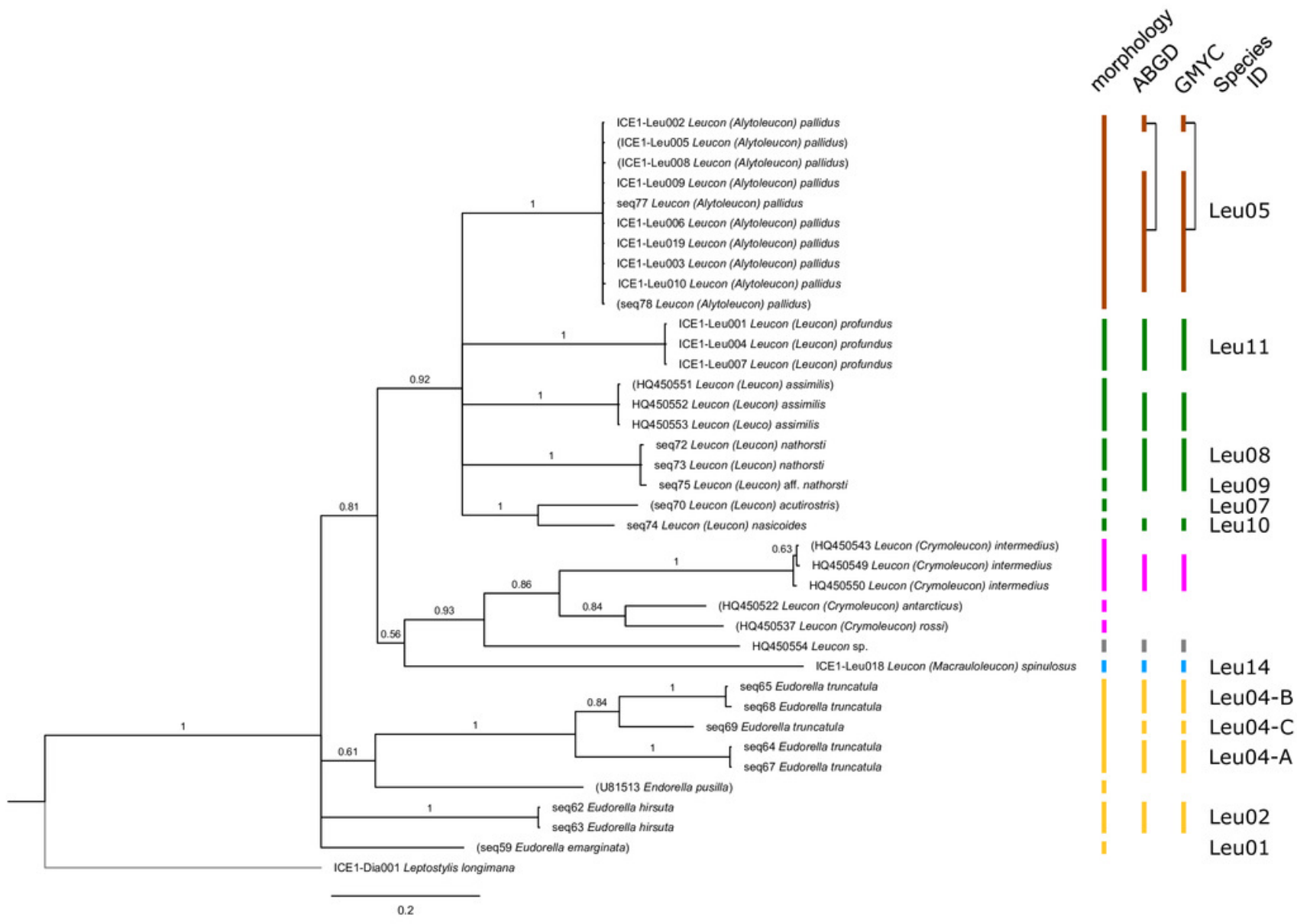


\section{Figure 4}

DATASET III - Phylogenetic relationships inferred by Bayesian analysis of the Bodotriidae and Nannastacidae.

The branch labels indicate posterior probability scores. The scale bar at the bottom of the tree shows nucleotide substitutions per site of sequence. Sequences in parentheses were excluded from genetic distance analyses due to insufficient sequence length. Vertical bars indicate the species delimited based on morphology, ABGD and GMYC with colors representing genera. Genetic lineages are separated by assigned letters A/B.
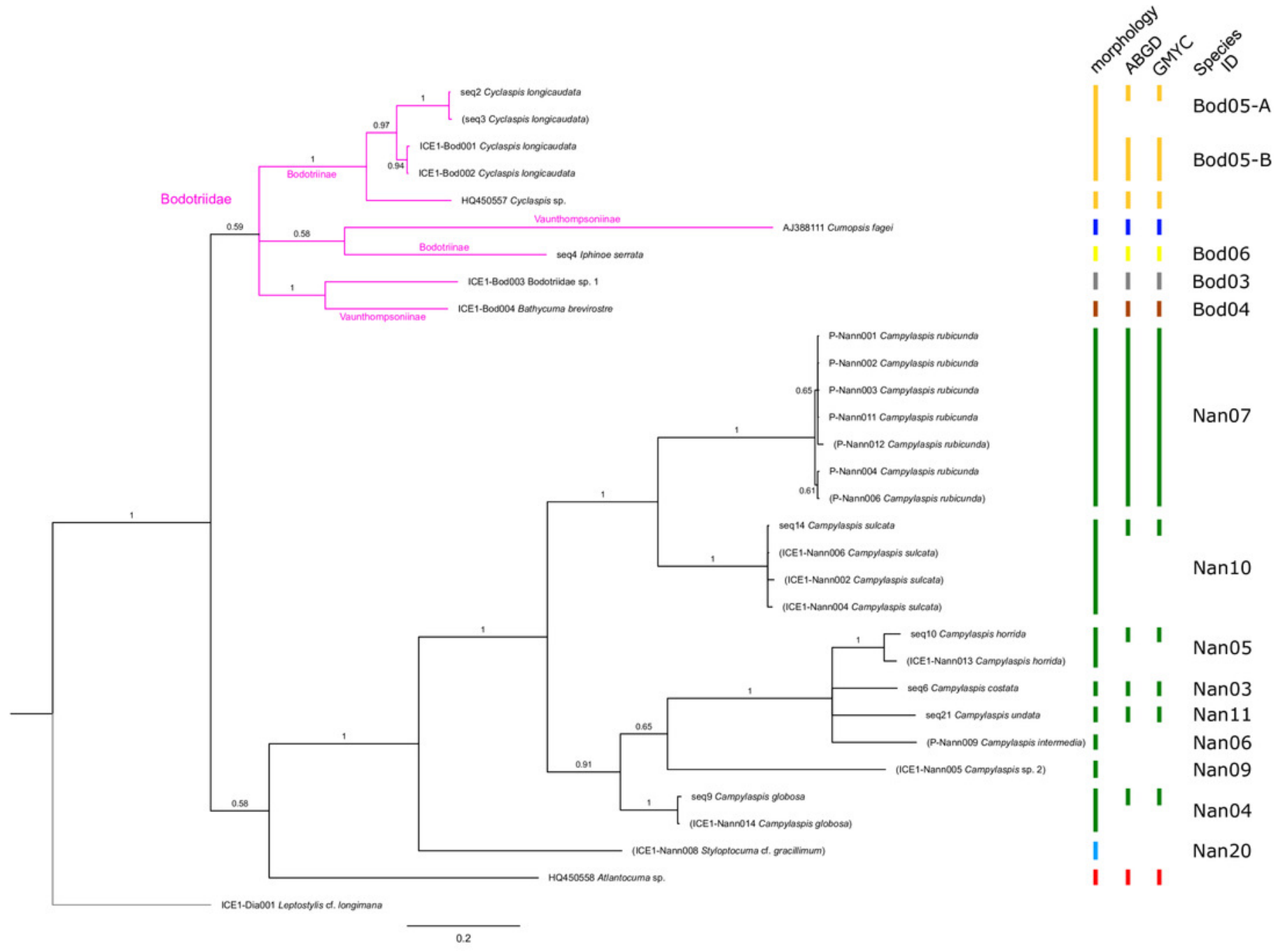


\section{Figure 5}

DATASET IV - Phylogenetic relationships inferred by Bayesian analysis of the Diastylidae and the Pseudocumatidae.

The branch labels indicate posterior probability scores. The scale bar at the bottom of the tree shows nucleotide substitutions per site of sequence. Sequences in parentheses were excluded from genetic distance analyses due to insufficient sequence length. Vertical bars indicate the species delimited based on morphology, ABGD and GMYC with colors representing genera. Connecting line in Dia14,-16-A,-16-B indicates the same putative species based on morphological identification. Genetic lineages are separated by assigned letters $A / B$. 

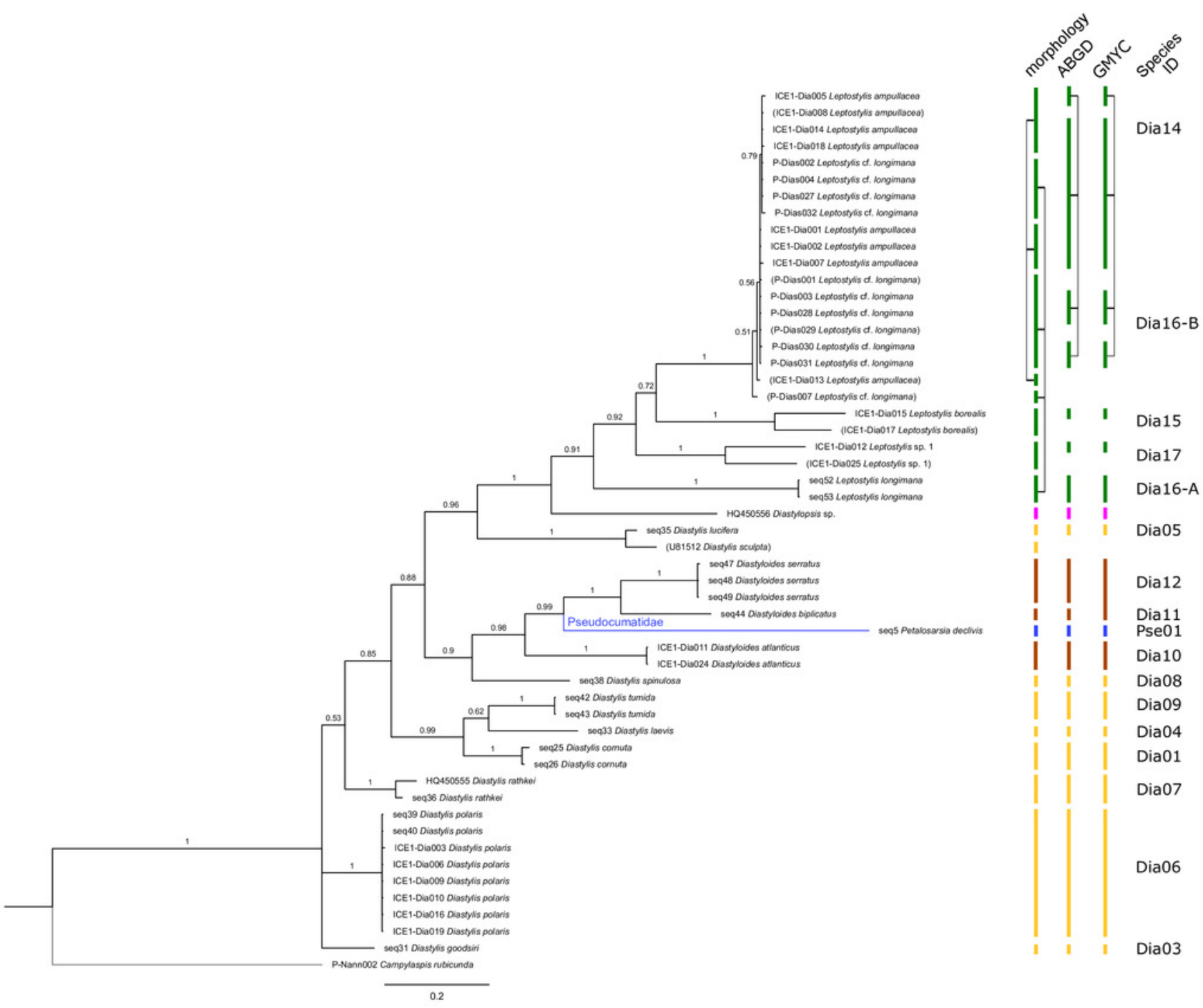


\section{Figure 6}

DATASET V - Phylogenetic relationships inferred by Bayesian analysis of Ceratocumatidae and Lampropidae.

The branch labels indicate posterior probability scores. The scale bar at the bottom of the tree shows nucleotide substitutions per site of sequence. Sequences in parentheses were excluded from genetic distance analyses due to insufficient sequence length. Vertical bars indicate the species delimited based on morphology, ABGD and GMYC with colors representing genera. Connecting line in Lam05 indicates the same putative species based on morphological identification. Genetic lineages are separated by assigned letters A/B. 

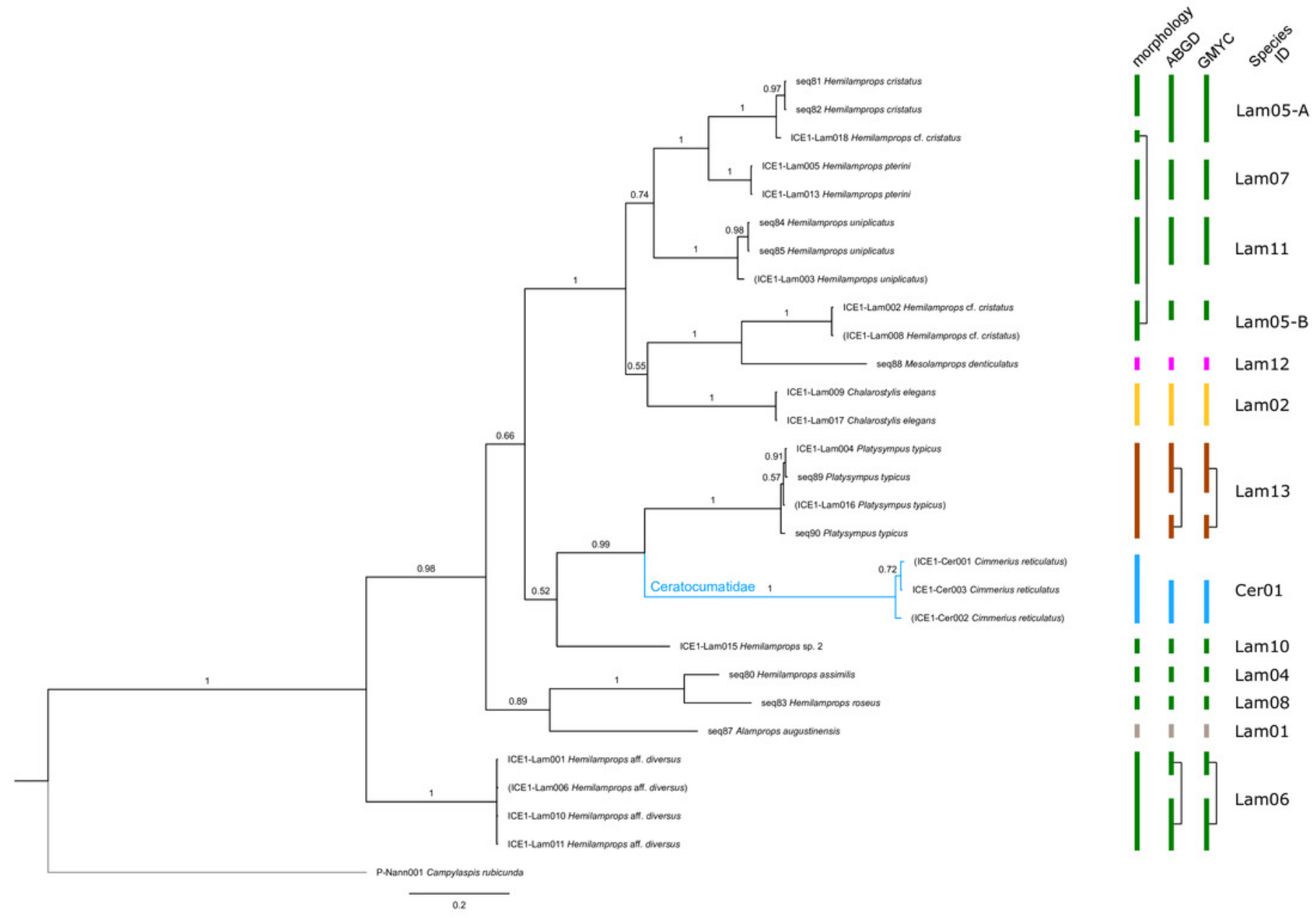


\section{Figure 7}

Summarized occurrence records of 'Cumacea' and their taxonomic level of determination.

(A) Occurrence data of present (OBIS) and newly added records (MAREANO, ICECU, literature) summarized and separated into the predefined marine ecoregions (1-8) and water masses (red: North Atlantic; black: Sub-Arctic; blue: Arctic). Bar plots show the total number of specimens and their taxonomic level of determination (see legend) in relation to the total

number of determined taxa. (B) Surface current branching of the North Atlantic current (4) entering the Arctic Ocean via the Norwegian Sea (5) up to Arctic water masses in the Kara Sea (8) and the outflow off the Greenland coast (3) passing the Denmark Strait (2) off Iceland (modified from Townsend 2012). 


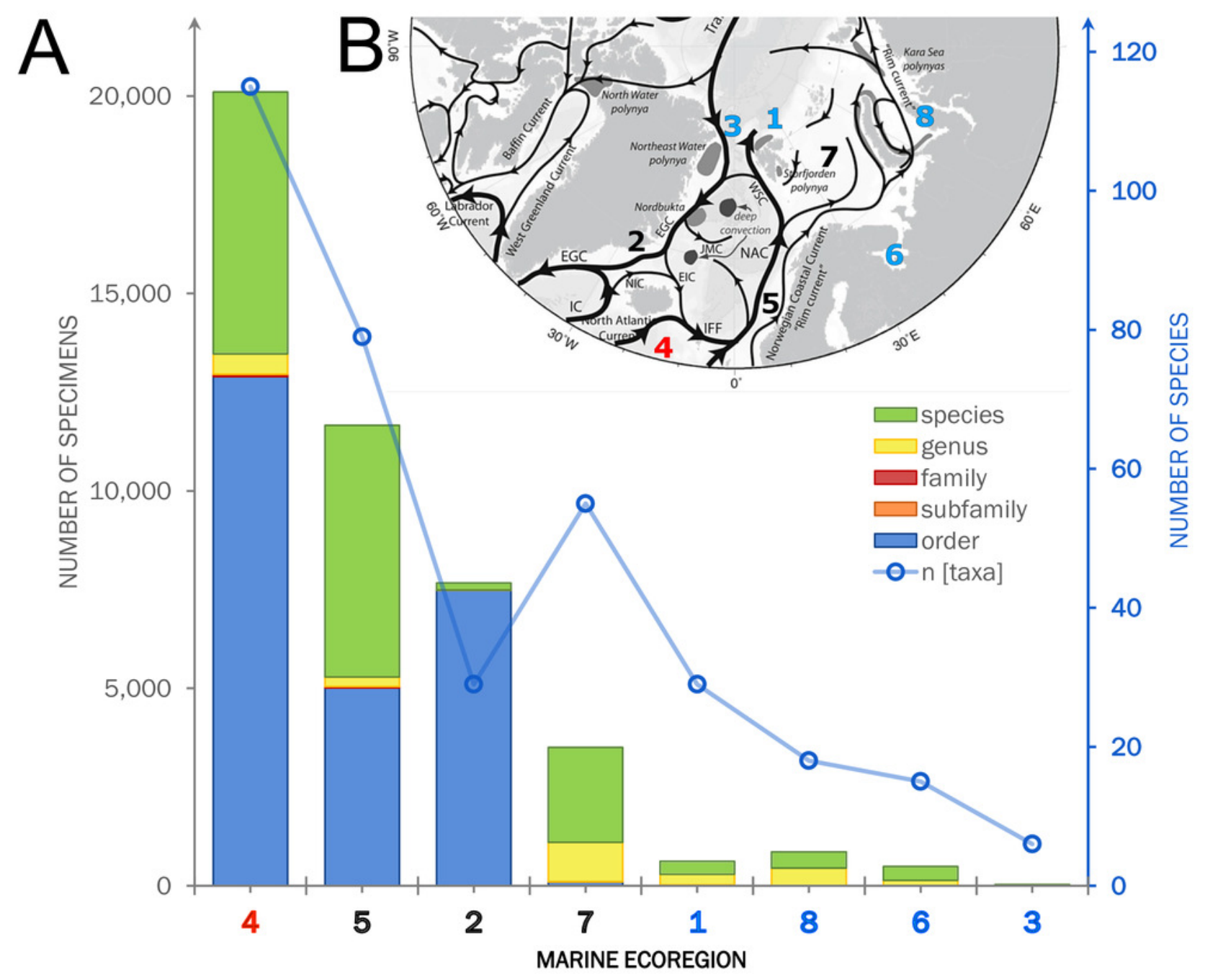




\section{Figure 8}

Occurrence records within defined ecoregions for the order Cumacea publicly accessible and additional records contributed by the new ICECU dataset.

Overview map for the order Cumacea of present occurrence records (blue), which are publicly accessible on the OBIS platform, and new records (orange), which were contributed by the MAREANO platform, the ICECU dataset and literature data within predefined water masses (red, North Atlantic; black, Sub-Arctic; cyan, Arctic) and ecoregions (1, Arctic Basin; 2, East Greenland Sea; 3, North Greenland Sea; 4, North Atlantic Ocean; 5, Norwegian Sea; 6, White Sea; 7, Barents Sea; 8, Kara Sea) after Curtis (1975), Hansen \& Østerhus (2000) and Schlichtholz \& Houssais (2002). Main focus of this study is on specimens from the bold highlighted ecoregions 1,2 and 4. 


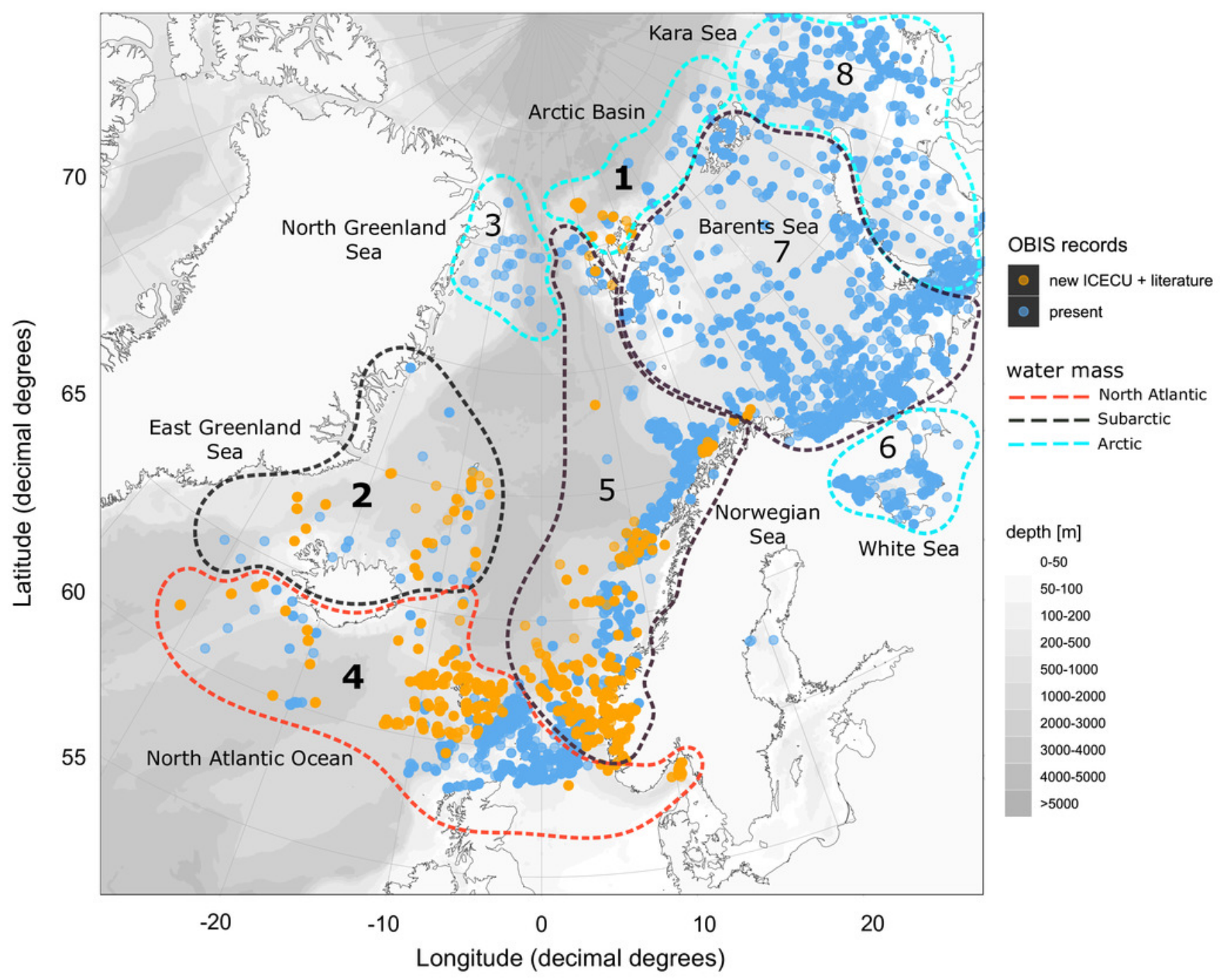




\section{Figure 9}

Relative family taxa composition, specimen count and predominating water masses at investigated stations of the ICECU dataset.

Each station was assigned to the predominating water mass (APW, Arctic Polar Water; ISOW, Iceland Sea Overflow Water; LSW, Labrador Sea Water; NAW, North Atlantic Water; NSAIW, Norwegian Sea Arctic Intermediate Water; NSDWc/w, cold/warm Norwegian Sea Deep Water). Circle size represents number of specimens and family taxa are distinguished by colors.

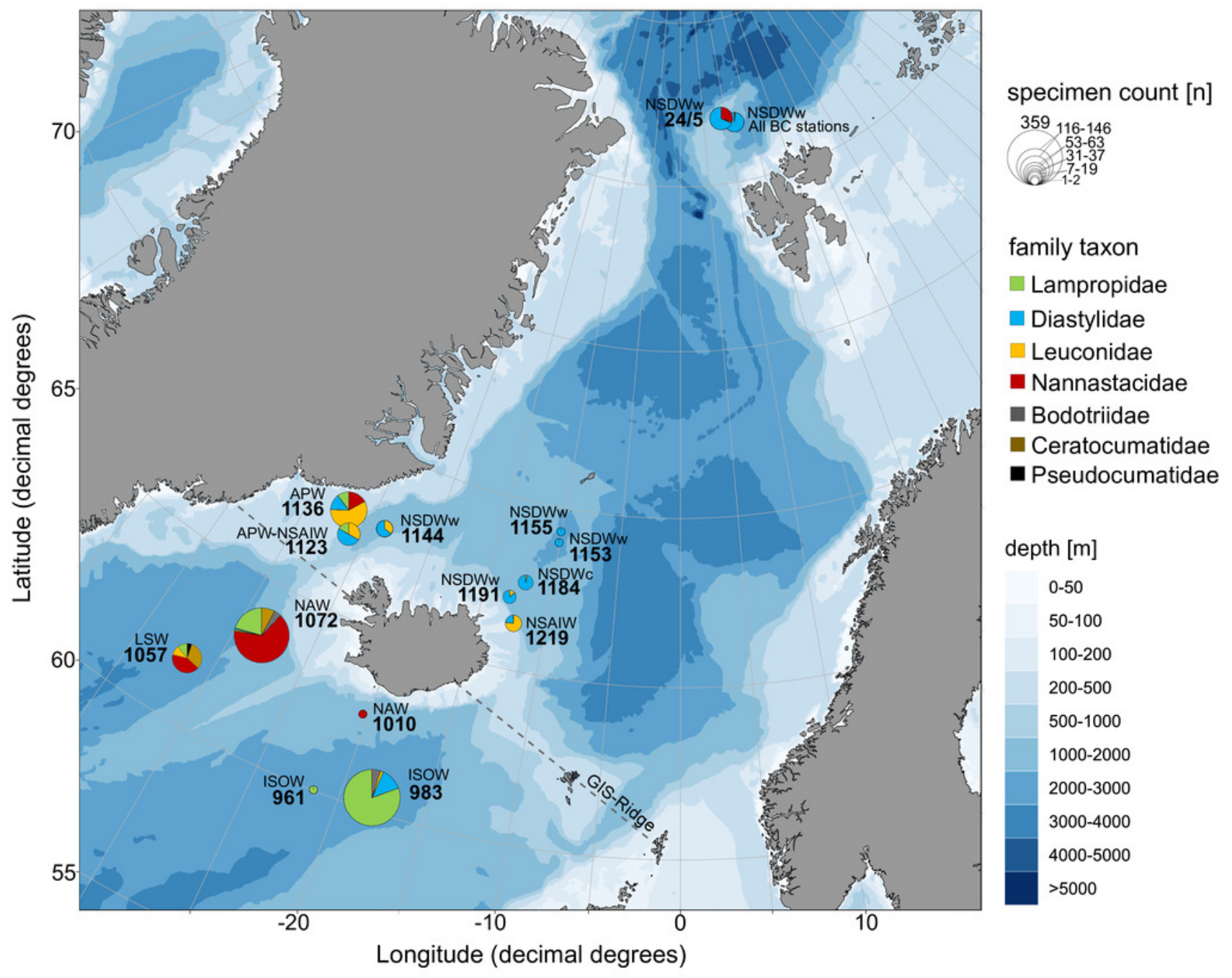




\section{Figure 10}

VENN-Diagram showing the total number of representative species per ecoregion as well as shared representatives occurring within several ecoregions.

Ecoregions are sorted by the extension of the North Atlantic Current from south to north. Created using the web-tool http://bioinformatics.psb.ugent.be/webtools/Venn/

\section{Norwegian Sea 2 East Greenland Sea}

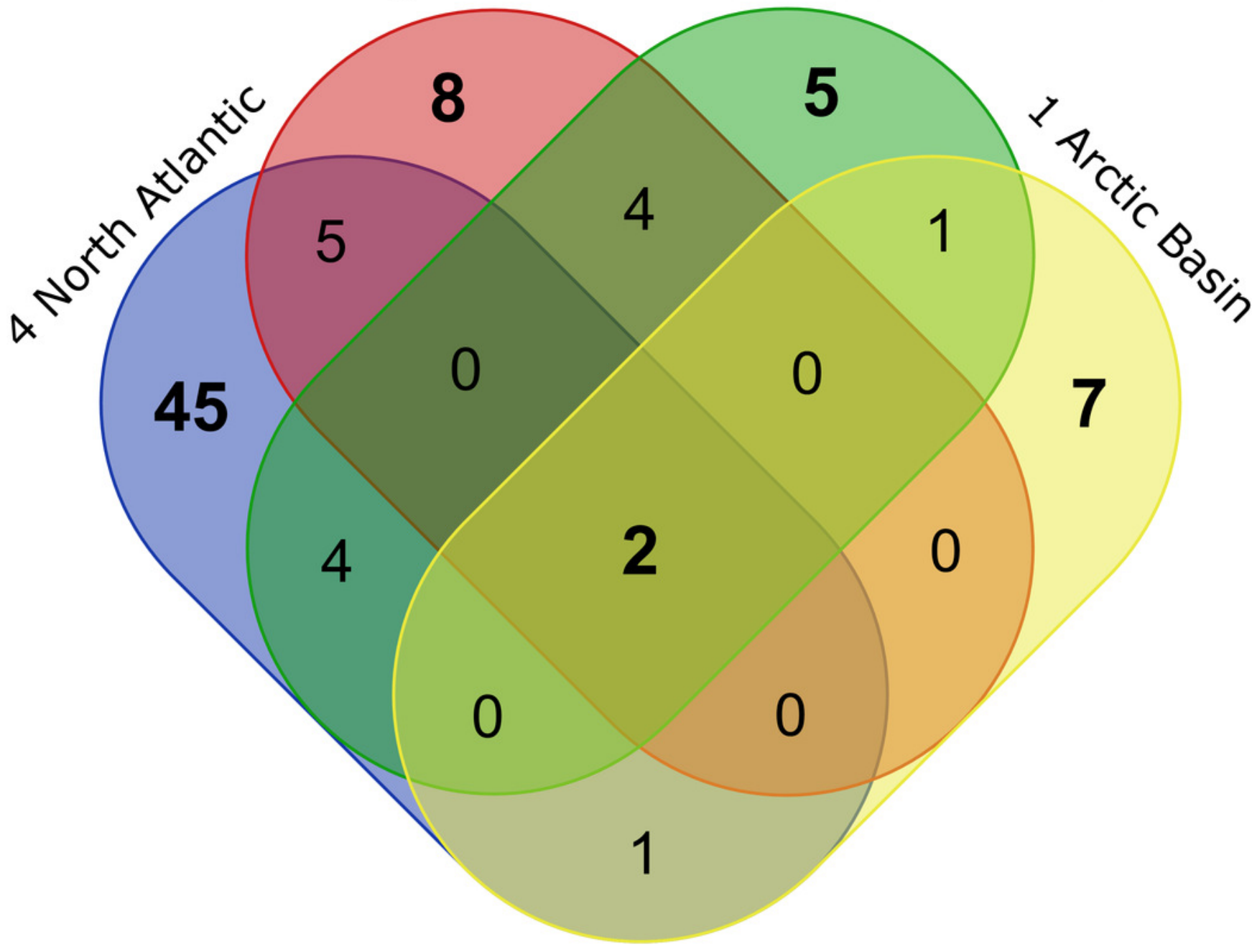




\section{Figure 11}

Distribution maps of species integrated in morphological and molecular analyses representing the families Diastylidae (A-C), Leuconidae (D) and Lampropidae (E-F).

Occurrences of morphologically identified species integrated in genetic analyses. Occurrence records are shown from the MAREANO and OBIS platform as well as literature data (blue), specimens morphologically investigated in this study (orange) and subsequently genetically investigated (grey triangle with sequence ID) and type and/or syntype locality of putative species (yellow star with reference literature). Genetic lineages are highlighted with dotted circles and separated by assigned letters A-C. 

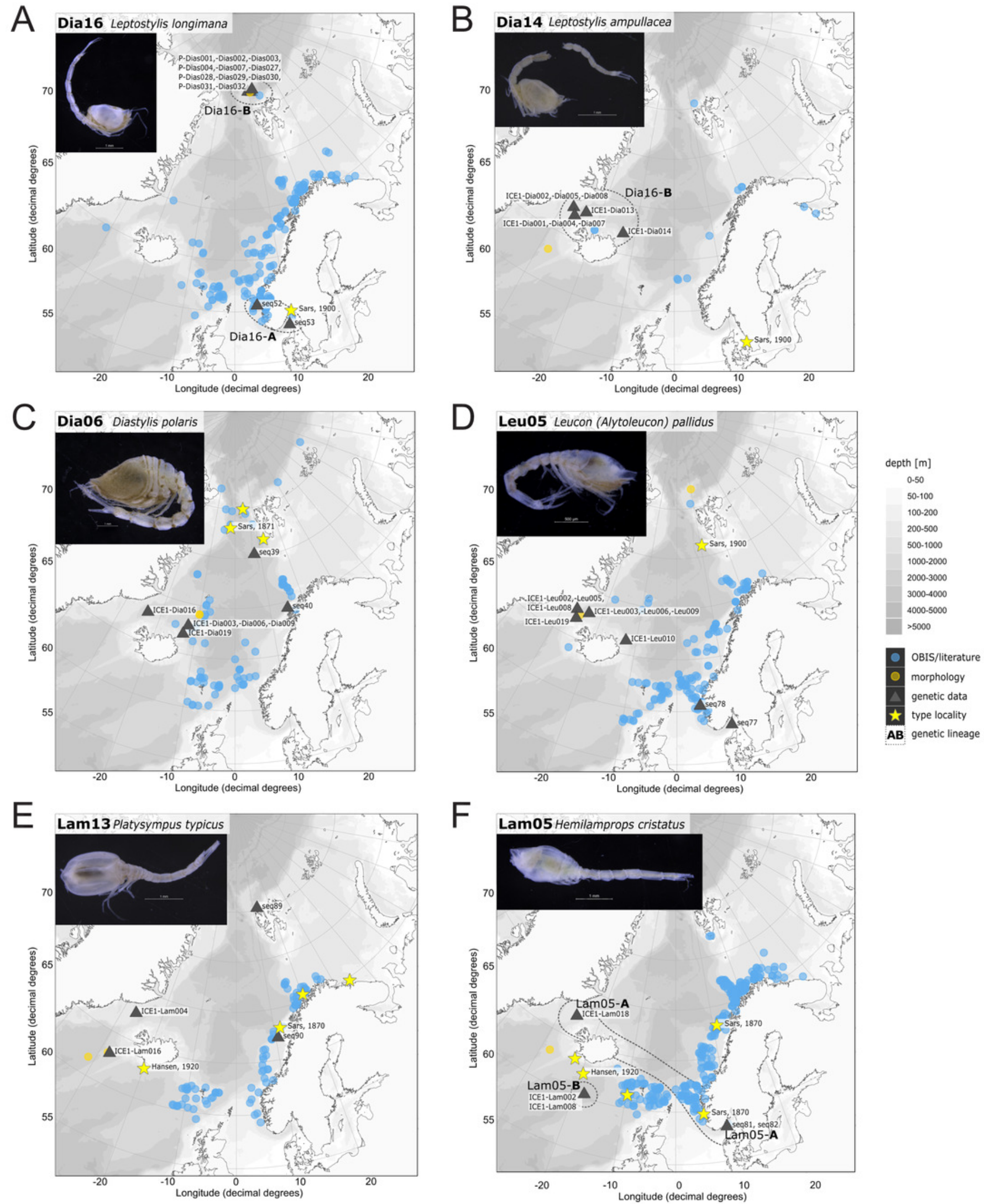
Figure 12

Distribution maps of species integrated in morphological and molecular analyses representing the families Diastylidae $(A, E)$, Lampropidae $(B, D)$, Ceratocumatidae $(C)$ and Nannastacidae (F).

Figure 11 continued. 

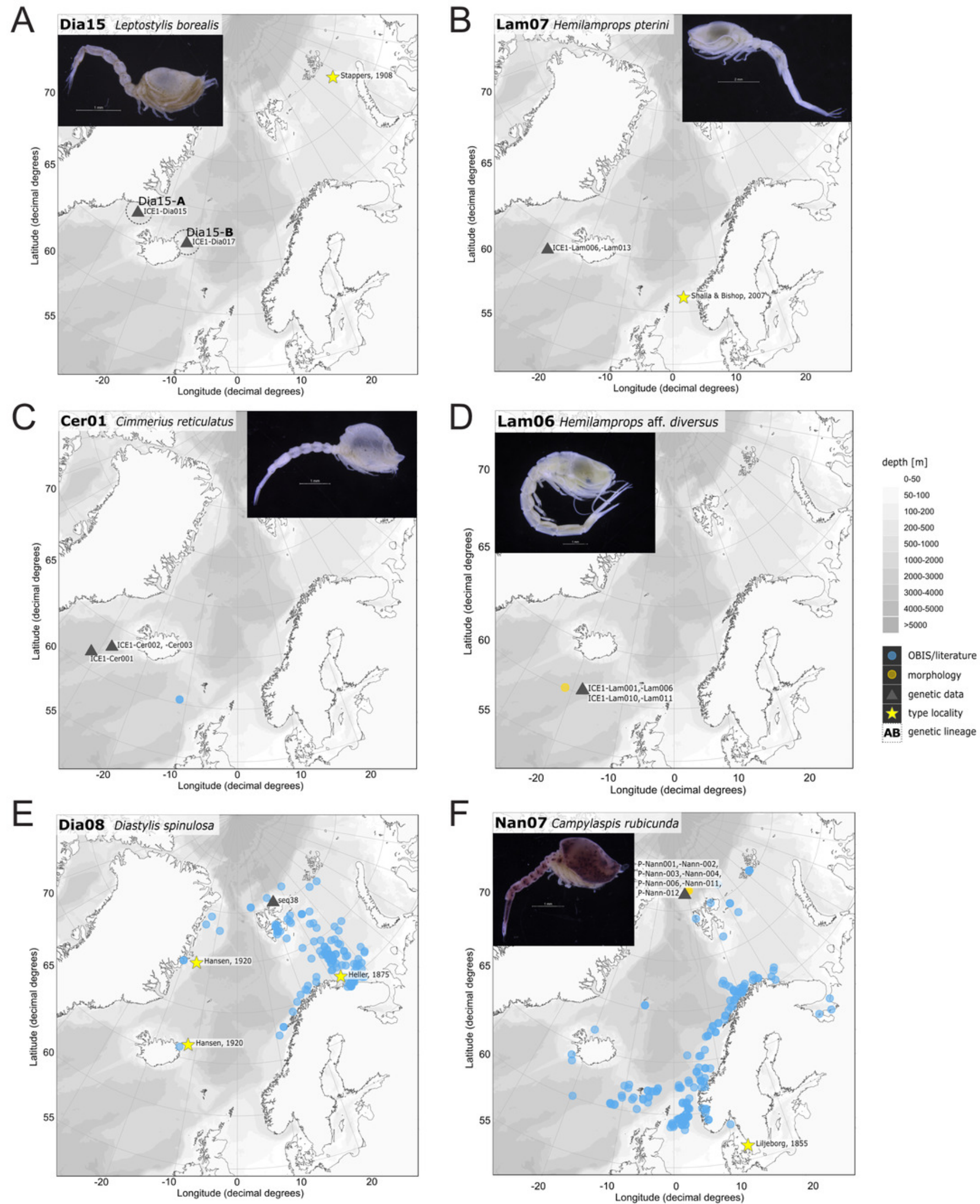
Figure 13

Distribution maps of species integrated in morphological and molecular analyses representing the families Nannastacidae $(A, C)$, Leuconidae (B), Diastylidae (D) and Bodotriidae (E).

Figure 11 continued. 

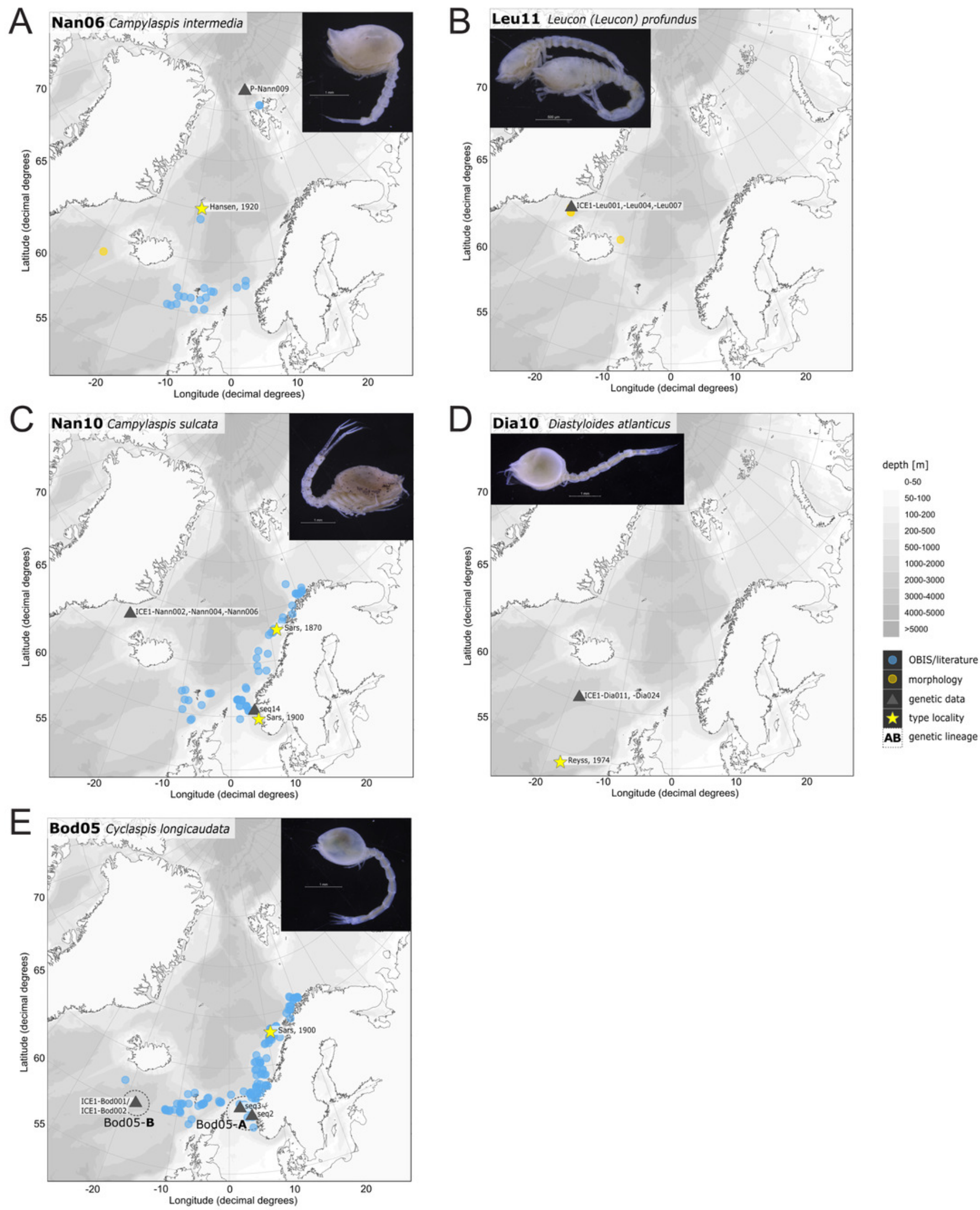


\section{Table $\mathbf{1}$ (on next page)}

Information on projects and sampled stations within the study area of Greenland, Iceland and Norwegian Sea (GIN-Seas).

Information (if applicable) include start and end position of gear deployment (Latitude/Longitude) and calculated haul distance, deployed gear type, depth, CTD-data on near bottom temperature and salinity, drift velocity of the vessel during PASCAL and assigned water masses after Schlichtholz \& Houssais (2002), Hansen \& Østerhus (2000), Brix $\&$ Svavarsson (2010) and Ostmann et al. (2014). 


\begin{tabular}{|c|c|c|c|c|c|c|c|c|c|c|c|c|c|c|c|c|}
\hline $\begin{array}{l}\text { Project/ } \\
\text { Expedition }\end{array}$ & Station & Area & Region & Habitat & Date & $\begin{array}{c}\text { Latitude } \\
\text { start }\end{array}$ & $\begin{array}{c}\text { Longitude } \\
\text { start }\end{array}$ & $\begin{array}{c}\text { Latitude } \\
\text { end }\end{array}$ & $\begin{array}{c}\text { Longitude } \\
\text { end }\end{array}$ & Gear & 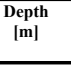 & $\begin{array}{c}\text { Temp. } \\
\text { bottom } \\
{\left[{ }^{\circ} \mathrm{C}\right]} \\
\end{array}$ & $\begin{array}{c}\text { Salinity } \\
\text { bottom } \\
\text { [tpt] } \\
\end{array}$ & $\begin{array}{c}\text { Haul } \\
\text { distance } \\
\text { [m] }\end{array}$ & 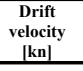 & Water mass \\
\hline Alaska & 90626 & N/A & Juneau (Alaska) & shelf & 26.06 .2009 & $58.37,690$ & $-134.56,69$ & $\mathrm{~N} / \mathrm{A}$ & N/A & $\begin{array}{l}\text { RP- } \\
\text { EBS }\end{array}$ & 1 & N/A & N/A & N/A & N/A & Alaska Coast \\
\hline BIOICE & BIOICE3669 & N/A & Iceland & shelf & 25.04 .2004 & $66.19,930$ & $-23.30,780$ & $\mathrm{~N} / \mathrm{A}$ & $\mathrm{N} / \mathrm{A}$ & $\begin{array}{l}\text { RP- } \\
\text { EBS }\end{array}$ & 158 & N/A & $\mathrm{N} / \mathrm{A}$ & $\mathrm{N} / \mathrm{A}$ & $\mathrm{N} / \mathrm{A}$ & Modified North Atlantic Water (MNAW) \\
\hline IceAGE & 961 & 1 & South Iceland Basin & $\begin{array}{l}\text { deep } \\
\text { sea }\end{array}$ & 28.08 .2011 & 60.0455 & -21.50233 & $\mathrm{~N} / \mathrm{A}$ & $\mathrm{N} / \mathrm{A}$ & $\mathrm{BC}$ & 2748 & 2.53 & 34.99 & N/A & N/A & ISOW \\
\hline IceAGE & 983 & 3 & South Iceland Basin & $\begin{array}{l}\text { deep } \\
\text { sea }\end{array}$ & 30.08 .2011 & 60.35733 & -18.135666 & 60.0455 & -18.14183 & $\begin{array}{l}\text { RP- } \\
\text { EBS }\end{array}$ & 2568 & 2.66 & 35 & 2462 & $\mathrm{~N} / \mathrm{A}$ & ISOW \\
\hline IceAGE & 1010 & 6 & South Iceland Basin & slope & 02.09 .2011 & 62.55166 & -20.39516 & 62.55366 & -20.38116 & $\begin{array}{l}\text { RP- } \\
\text { EBS }\end{array}$ & 1385 & 3.88 & 35.02 & N/A & N/A & NAW \\
\hline IceAGE & 1057 & 11 & South Iceland Irminger Basin & $\begin{array}{l}\text { deep } \\
\text { sea }\end{array}$ & 07.09 .2011 & 61.64166 & -31.35616 & 61.654 & -31.34916 & $\begin{array}{l}\text { RP- } \\
\text { EBS }\end{array}$ & 2505 & 3.16 & 34.94 & 1983 & $\mathrm{~N} / \mathrm{A}$ & LSW \\
\hline IceAGE & 1072 & 13 & South Iceland Irminger Basin & $\begin{array}{l}\text { deep } \\
\text { sea }\end{array}$ & 08.09 .2011 & 63.00766 & -28.06816 & 63.01833 & -28.0525 & $\begin{array}{l}\text { RP- } \\
\text { EBS }\end{array}$ & 1594 & 4.28 & 34.99 & 1673 & N/A & NAW \\
\hline IceAGE & 1123 & 19 & East Greenland Denmark Strait & slope & 14.09.2011 & 67.21383 & -26.2075 & 67.21466 & -26.19216 & $\begin{array}{l}\text { RP- } \\
\text { EBS }\end{array}$ & 716.5 & 0.07 & 34.91 & 670 & $\mathrm{~N} / \mathrm{A}$ & APW/NSAIW \\
\hline IceAGE & 1136 & 20 & East Greenland Denmark Strait & shelf & 14.09.2011 & 67.63583 & -26.7665 & 67.63266 & -26.77366 & $\begin{array}{l}\text { Cliled } \\
\text { Sled }\end{array}$ & 316 & 0.71 & 34.63 & 366 & $\mathrm{~N} / \mathrm{A}$ & APW \\
\hline IceAGE & 1144 & 21 & East Greenland Denmark Strait & $\begin{array}{l}\text { deep } \\
\text { sea }\end{array}$ & 15.09 .2011 & 67.86783 & -23.69633 & 67.8595 & -23.69616 & $\begin{array}{l}\text { RP- } \\
\text { EBS }\end{array}$ & 1281 & -0.67 & 34.91 & 1340 & $\mathrm{~N} / \mathrm{A}$ & $\mathrm{NSDWw}_{\mathrm{w}}$ \\
\hline IceAGE & 1153 & 22 & $\begin{array}{l}\text { North-East Iceland Norwegian } \\
\text { Basin }\end{array}$ & $\begin{array}{l}\text { deep } \\
\text { sea }\end{array}$ & 17.09 .2011 & 69.09333 & -9.9335 & $\mathrm{~N} / \mathrm{A}$ & $\mathrm{N} / \mathrm{A}$ & $\mathrm{BC}$ & 2174 & -0.75 & 34.91 & $\mathrm{~N} / \mathrm{A}$ & N/A & NSDWw \\
\hline IceAGE & 1155 & 22 & $\begin{array}{l}\text { North-East Iceland Norwegian } \\
\text { Basin }\end{array}$ & $\begin{array}{l}\text { deep } \\
\text { sea }\end{array}$ & 17.09.2011 & 69.11483 & -9.912 & 69.10616 & -9.9205 & $\begin{array}{l}\text { Brenke } \\
\text { Sled }\end{array}$ & 2204 & -0.75 & 34.91 & 1582 & $\mathrm{~N} / \mathrm{A}$ & NSDWw \\
\hline IceAGE & 1184 & 26 & Norwegian Sea Basin & $\begin{array}{l}\text { deep } \\
\text { sea }\end{array}$ & 20.09 .2011 & 67.64383 & -12.162 & 67.63866 & -12.138 & $\begin{array}{l}\text { RP- } \\
\text { EBS }\end{array}$ & 1819 & -0.85 & 34.91 & 1885 & $\mathrm{~N} / \mathrm{A}$ & NSDWc \\
\hline IceAGE & 1191 & 27 & $\begin{array}{l}\text { North-East Iceland Norwegian } \\
\text { Sea }\end{array}$ & $\begin{array}{l}\text { deep } \\
\text { sea }\end{array}$ & 21.09.2011 & 67.07866 & -13.06383 & 67.07516 & -13.03816 & $\begin{array}{l}\text { RP- } \\
\text { EBS }\end{array}$ & 1575 & -0.74 & 34.91 & 1795 & $\mathrm{~N} / \mathrm{A}$ & $\mathrm{NSDW}_{\mathrm{w}}$ \\
\hline IceAGE & 1219 & 30 & East Iceland Norwegian Sea & slope & 22.09 .2011 & 66.289 & -12.347 & 66.2925 & -12.355 & $\begin{array}{l}\text { RP- } \\
\text { EBS }\end{array}$ & 579 & -0.4 & 34.9 & 760 & N/A & NSAIW \\
\hline MAREANO & R488-379, BT & N/A & Eggakanten (Norway) & $\begin{array}{l}\text { deep } \\
\text { sea }\end{array}$ & 10.10.2009 & $69.43,760$ & $15.11,110$ & $\mathrm{~N} / \mathrm{A}$ & $\mathrm{N} / \mathrm{A}$ & $\begin{array}{l}\text { Beam } \\
\text { Trawl }\end{array}$ & 2241 & N/A & N/A & $\mathrm{N} / \mathrm{A}$ & $\mathrm{N} / \mathrm{A}$ & Norwegian Coastal Current \\
\hline MAREANO & $\mathrm{R} 721-126, \mathrm{RP}$ & N/A & Continental shelf (Norway) & shelf & 25.07 .2011 & $67.50,810$ & $11.48,850$ & $\mathrm{~N} / \mathrm{A}$ & $\mathrm{N} / \mathrm{A}$ & $\begin{array}{l}\text { RP- } \\
\text { EBS }\end{array}$ & 183 & $\mathrm{~N} / \mathrm{A}$ & N/A & N/A & $\mathrm{N} / \mathrm{A}$ & Norwegian Coastal Current \\
\hline MAREANO & $\mathrm{R} 754-132, \mathrm{RP}$ & N/A & Continental slope (Norway) & slope & 22.09 .2011 & $67.48,275$ & $09.41,126$ & $\mathrm{~N} / \mathrm{A}$ & $\mathrm{N} / \mathrm{A}$ & $\begin{array}{l}\text { RP- } \\
\text { EBS }\end{array}$ & 823 & N/A & N/A & N/A & $\mathrm{N} / \mathrm{A}$ & Warm Atlantic Current \\
\hline MAREANO & R814-22, RP & $\mathrm{N} / \mathrm{A}$ & Continental shelf (Norway) & shelf & 11.05 .2012 & $67.39,220$ & $10.18,580$ & $\mathrm{~N} / \mathrm{A}$ & $\mathrm{N} / \mathrm{A}$ & $\begin{array}{l}\text { RP- } \\
\text { EBS }\end{array}$ & 224 & $\mathrm{~N} / \mathrm{A}$ & N/A & $\mathrm{N} / \mathrm{A}$ & $\mathrm{N} / \mathrm{A}$ & Norwegian Coastal Current \\
\hline PASCAL & $22-3$ & N/A & Yermak Plateau & $\begin{array}{l}\text { deep } \\
\text { sea }\end{array}$ & 05.06 .2017 & 81.93248 & 10.959499 & $\mathrm{~N} / \mathrm{A}$ & $\mathrm{N} / \mathrm{A}$ & $\mathrm{BC}$ & 1077 & -0.55 & 34.91 & N/A & 0.1 & NSDWw \\
\hline PASCAL & $24-5$ & N/A & Yermak Plateau & slope & 07.06.2017 & 81.927034 & 10.13311 & 81.921801 & 10.055294 & EBS & 955 & -0.48 & 34.92 & 1345 & 0.3 & NSDWw \\
\hline PASCAL & $25-5$ & N/A & Yermak Plateau & slope & 08.06 .2017 & 81.896594 & 9.855325 & $\mathrm{~N} / \mathrm{A}$ & $\mathrm{N} / \mathrm{A}$ & $\mathrm{BC}$ & 931 & N/A & $\mathrm{N} / \mathrm{A}$ & $\mathrm{N} / \mathrm{A}$ & 0 & $\mathrm{NSDWw}_{\mathrm{w}}$ \\
\hline PASCAL & $29-4 / 5$ & N/A & Yermak Plateau & $\begin{array}{l}\text { deep } \\
\text { sea }\end{array}$ & 12.06 .2017 & 81.820493 & 11.566229 & $\mathrm{~N} / \mathrm{A}$ & $\mathrm{N} / \mathrm{A}$ & $\mathrm{BC}$ & 1564 & -0.74 & 34.92 & $\mathrm{~N} / \mathrm{A}$ & 0.1 & NSDWw \\
\hline PASCAL & $29-7$ & N/A & Yermak Plateau & $\begin{array}{l}\text { deep } \\
\text { sea }\end{array}$ & 12.06 .2017 & 81.815543 & 11.54354 & $\mathrm{~N} / \mathrm{A}$ & $\mathrm{N} / \mathrm{A}$ & $\mathrm{BC}$ & 1569 & -0.74 & 34.92 & $\mathrm{~N} / \mathrm{A}$ & 0.1 & NSDWw \\
\hline PASCAL & $30-1$ & $\mathrm{~N} / \mathrm{A}$ & Yermak Plateau & $\begin{array}{l}\text { deep } \\
\text { sea }\end{array}$ & 13.06 .2017 & 81.822024 & 11.538371 & $\mathrm{~N} / \mathrm{A}$ & $\mathrm{N} / \mathrm{A}$ & $\mathrm{BC}$ & 1547 & -0.72 & 34.92 & $\mathrm{~N} / \mathrm{A}$ & 0.1 & NSDWw \\
\hline PASCAL & $32-3$ & N/A & Yermak Plateau & $\begin{array}{l}\text { deep } \\
\text { sea }\end{array}$ & 15.06.2017 & 81.728044 & 10.851854 & $\mathrm{~N} / \mathrm{A}$ & $\mathrm{N} / \mathrm{A}$ & $\mathrm{BC}$ & 1581 & -0.7 & 34.92 & N/A & 0.1 & NSDWw \\
\hline PASCAL & $32-4$ & N/A & Yermak Plateau & $\begin{array}{l}\text { deep } \\
\text { sea }\end{array}$ & 15.06 .2017 & 81.720718 & 10.811252 & N/A & N/A & $\mathrm{BC}$ & 1543 & -0.7 & 34.92 & $\mathrm{~N} / \mathrm{A}$ & 0.2 & NSDWw \\
\hline
\end{tabular}




\begin{tabular}{|c|c|c|c|c|c|c|c|c|c|c|c|c|c|c|c|c|}
\hline $\begin{array}{c}\text { Project// } \\
\text { Expedition }\end{array}$ & Station & Area & Region & Habitat & Date & $\begin{array}{c}\begin{array}{c}\text { Latitude } \\
\text { start }\end{array} \\
\end{array}$ & $\begin{array}{c}\text { Longitude } \\
\text { start }\end{array}$ & 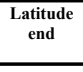 & $\begin{array}{c}\text { Longitude } \\
\text { end }\end{array}$ & Gear & 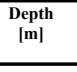 & $\begin{array}{c}\text { Temp. } \\
\text { bottom } \\
{\left[{ }^{\circ} \mathrm{C}\right]} \\
\end{array}$ & $\begin{array}{c}\text { Salinity } \\
\text { bottom } \\
{[|\mathrm{ppt}|} \\
\end{array}$ & $\begin{array}{c}\text { Haul } \\
\text { distance } \\
{[\mathbf{m}]}\end{array}$ & $\begin{array}{c}\text { Drift } \\
\text { velocity } \\
\mid \begin{array}{l}\mathrm{kn} \mid \\
\end{array}\end{array}$ & Water mass \\
\hline UоB & $09.01 .28-2$ & $\mathrm{~N} / \mathrm{A}$ & Fanafjorden (Norway) & shelf & 28.01 .2009 & $60.16,440$ & $05.11,050$ & N/A & N/A & $\begin{array}{l}\text { RP- } \\
\text { EBS }\end{array}$ & 180 & N/A & $\mathrm{N} / \mathrm{A}$ & N/A & N/A & Fjord \\
\hline UoB & $11.01 .19-1$ & N/A & Fensfjorden (Norway) & shelf & 19.01 .2011 & $60.50,856$ & $04.51,702$ & N/A & N/A & $\begin{array}{l}\text { RP- } \\
\text { EBS }\end{array}$ & 460 & N/A & $\mathrm{N} / \mathrm{A}$ & N/A & $\mathrm{N} / \mathrm{A}$ & Fjord \\
\hline UoB & $11.01 .21-1$ & $\mathrm{~N} / \mathrm{A}$ & Hjeltefjorden (Norway) & shelf & 21.01 .2011 & $60.37,600$ & $04.52,400$ & N/A & N/A & $\begin{array}{l}\text { RP- } \\
\text { EBS }\end{array}$ & 205 & N/A & $\mathrm{N} / \mathrm{A}$ & N/A & N/A & Fjord \\
\hline Чов & $11.03 .09-1$ & N/A & Fensfforden (Norway) & shelf & 09.03 .2011 & $60.51,935$ & $04.54,384$ & N/A & $\mathrm{N} / \mathrm{A}$ & $\begin{array}{l}\text { RP- } \\
\text { EBS }\end{array}$ & 462 & N/A & N/A & N/A & N/A & Fjord \\
\hline Uов & $11.03 .11-2$ & $\mathrm{~N} / \mathrm{A}$ & Hjeltefjorden (Norway) & shelf & 11.03 .2011 & $60.37,320$ & $04.52,794$ & N/A & N/A & $\begin{array}{l}\text { RP- } \\
\text { EBS }\end{array}$ & 239 & N/A & N/A & N/A & $\mathrm{N} / \mathrm{A}$ & Fjord \\
\hline UoB & $11.05 .10-1$ & $\mathrm{~N} / \mathrm{A}$ & Sognesjøen (Norway) & shelf & 10.05 .2011 & $60.55,048$ & $04.38,225$ & N/A & N/A & $\begin{array}{l}\text { RP- } \\
\text { EBS }\end{array}$ & 550 & N/A & $\mathrm{N} / \mathrm{A}$ & N/A & N/A & Norwegian Coastal Current \\
\hline Чoв & $11.05 .10-3$ & $\mathrm{~N} / \mathrm{A}$ & Sognesjøen (Norway) & shelf & 10.05 .2011 & 60.57 .986 & 04.40 .912 & $\mathrm{~N} / \mathrm{A}$ & N/A & $\begin{array}{l}\text { RP- } \\
\text { EBS }\end{array}$ & 381 & N/A & $\mathrm{N} / \mathrm{A}$ & N/A & N/A & Norwegian Coastal Current \\
\hline UoB & $11.05 .11-2 \mathrm{C}$ & $\mathrm{N} / \mathrm{A}$ & Førdefjorden (Norway) & shelf & 11.05 .2011 & $61.29,106$ & $05.21,497$ & N/A & N/A & $\begin{array}{l}\text { RP- } \\
\text { EBS }\end{array}$ & 335 & N/A & N/A & N/A & N/A & Fjord \\
\hline Чов & $11.05 .15-1$ & N/A & Hjeltefjorden (Norway) & shelf & 15.05 .2011 & $60.37,600$ & $04.52,300$ & $\mathrm{~N} / \mathrm{A}$ & $\mathrm{N} / \mathrm{A}$ & $\begin{array}{l}\text { RP- } \\
\text { EBS }\end{array}$ & 240 & $\mathrm{~N} / \mathrm{A}$ & $\mathrm{N} / \mathrm{A}$ & $\mathrm{N} / \mathrm{A}$ & $\mathrm{N} / \mathrm{A}$ & Fjord \\
\hline UoB & BS 14-19 & $\mathrm{N} / \mathrm{A}$ & Skagerak (Norway) & shelf & 13.05 .2009 & $58.22,101$ & $10.20,572$ & N/A & N/A & $\begin{array}{l}\text { RP- } \\
\text { EBS }\end{array}$ & 407 & N/A & $\mathrm{N} / \mathrm{A}$ & N/A & $\mathrm{N} / \mathrm{A}$ & Mixed Atlantic/Baltic \\
\hline UoB & BS 22-32 & $\mathrm{N} / \mathrm{A}$ & Skagerak (Norway) & shelf & 14.05 .2009 & $58.28,908$ & $10.26,612$ & $\mathrm{~N} / \mathrm{A}$ & N/A & $\begin{array}{l}\text { RP- } \\
\text { EBS }\end{array}$ & 301 & N/A & $\mathrm{N} / \mathrm{A}$ & N/A & N/A & Mixed Atlantic/Baltic \\
\hline UoB & BS 28-44 & $\mathrm{N} / \mathrm{A}$ & Skagerak (Norway) & shelf & 14.05.2009 & $58.37,710$ & $10.22,558$ & N/A & $\mathrm{N} / \mathrm{A}$ & $\begin{array}{l}\text { RP- } \\
\text { EBS }\end{array}$ & 251 & N/A & $\mathrm{N} / \mathrm{A}$ & N/A & $\mathrm{N} / \mathrm{A}$ & Mixed Atlantic/Baltic \\
\hline Uов & BS 34-56 & $\mathrm{N} / \mathrm{A}$ & Skagerak (Norway) & slope & 15.05 .2009 & $58.28,172$ & $10.07,999$ & $\mathrm{~N} / \mathrm{A}$ & $\mathrm{N} / \mathrm{A}$ & $\begin{array}{l}\text { RP- } \\
\text { EBS }\end{array}$ & 513 & $\mathrm{~N} / \mathrm{A}$ & $\mathrm{N} / \mathrm{A}$ & $\mathrm{N} / \mathrm{A}$ & N/A & Mixed Atlantic/Baltic \\
\hline UоB & BS $75-135$ & N/A & Skagerak (Norway) & shelf & 19.05 .2009 & $58.51,456$ & $10.26,348$ & N/A & N/A & $\begin{array}{l}\text { RP- } \\
\text { EBS }\end{array}$ & 246 & N/A & $\mathrm{N} / \mathrm{A}$ & N/A & N/A & Mixed Atlantic/Baltic \\
\hline UoB & BS $82-147$ & N/A & Skagerak (Norway) & shelf & 20.05 .2009 & $58.37,258$ & $10.03,077$ & $\mathrm{~N} / \mathrm{A}$ & $\mathrm{N} / \mathrm{A}$ & $\begin{array}{l}\text { RP- } \\
\text { EBS }\end{array}$ & 484 & $\mathrm{~N} / \mathrm{A}$ & $\mathrm{N} / \mathrm{A}$ & N/A & N/A & Mixed Atlantic/Baltic \\
\hline UoB & BS 86-151 & $\mathrm{N} / \mathrm{A}$ & Skagerak (Norway) & slope & 20.05 .2009 & $58.25,540$ & $09.38,836$ & $\mathrm{~N} / \mathrm{A}$ & N/A & $\begin{array}{l}\text { RP- } \\
\text { EBS }\end{array}$ & 710 & N/A & $\mathrm{N} / \mathrm{A}$ & N/A & $\mathrm{N} / \mathrm{A}$ & Mixed Atlantic/Baltic \\
\hline Uов & H2DEEP-RP-1 & N/A & Jan Mayen & $\begin{array}{l}\text { deep } \\
\text { sea }\end{array}$ & 05.08 .2009 & $75.35,340$ & $07.45,390$ & N/A & N/A & $\begin{array}{l}\text { RP- } \\
\text { EBS }\end{array}$ & 2542 & N/A & N/A & N/A & N/A & $\mathrm{N} / \mathrm{A}$ \\
\hline UoB & KV-09 2011 & Sektor 4 & Continental shelf (Norway) & shelf & 03.06 .2011 & 61.08376 & 2.49373 & $\mathrm{~N} / \mathrm{A}$ & N/A & Grab & 191 & $\mathrm{~N} / \mathrm{A}$ & N/A & $\mathrm{N} / \mathrm{A}$ & N/A & Norwegian Coastal Current \\
\hline UoB & SFND-08R 2011 & $\mathrm{~N} / \mathrm{A}$ & Continental shelf (Norway) & shelf & 31.05 .2011 & 61.48140 & 1.85231 & N/A & $\mathrm{N} / \mathrm{A}$ & Grab & 273 & N/A & $\mathrm{N} / \mathrm{A}$ & N/A & $\mathrm{N} / \mathrm{A}$ & Norwegian Coastal Current \\
\hline UoB & UNIS 2007-129 & $\mathrm{N} / \mathrm{A}$ & Svalbard & shelf & 04.09.2007 & $80.05,008$ & $22.11,834$ & N/A & N/A & $\begin{array}{l}\text { RP- } \\
\text { EBS }\end{array}$ & 188 & N/A & N/A & N/A & N/A & NSDWw \\
\hline UоB & UNIS 2009-27 & $\mathrm{N} / \mathrm{A}$ & Svalbard & shelf & 01.09.2009 & $80.09,141$ & $16.56,126$ & N/A & N/A & $\begin{array}{l}\text { RP- } \\
\text { EBS }\end{array}$ & 340 & N/A & $\mathrm{N} / \mathrm{A}$ & N/A & N/A & NSDWw \\
\hline Uов & UNIS 2009-36 & N/A & Svalbard & shelf & 01.09 .2009 & $79.36,693$ & $18.55,051$ & $\mathrm{~N} / \mathrm{A}$ & N/A & $\begin{array}{l}\text { RP- } \\
\text { EBS }\end{array}$ & 337 & $\mathrm{~N} / \mathrm{A}$ & $\mathrm{N} / \mathrm{A}$ & $\mathrm{N} / \mathrm{A}$ & $\mathrm{N} / \mathrm{A}$ & NSDWw \\
\hline UoB & UNIS 2009-4 & $\mathrm{N} / \mathrm{A}$ & Svalbard & shelf & 25.08 .2009 & $78.18,300$ & $14.29,000$ & $\mathrm{~N} / \mathrm{A}$ & $\mathrm{N} / \mathrm{A}$ & Dredge & 56 & $\mathrm{~N} / \mathrm{A}$ & $\mathrm{N} / \mathrm{A}$ & $\mathrm{N} / \mathrm{A}$ & N/A & NSDWw \\
\hline UoB & UNIS 2009-71 & $\mathrm{N} / \mathrm{A}$ & Svalbard & shelf & 04.09.2009 & $80.27,453$ & $12.20,208$ & $\mathrm{~N} / \mathrm{A}$ & $\mathrm{N} / \mathrm{A}$ & $\begin{array}{l}\text { RP- } \\
\text { EBS }\end{array}$ & 497 & $\mathrm{~N} / \mathrm{A}$ & $\mathrm{N} / \mathrm{A}$ & $\mathrm{N} / \mathrm{A}$ & N/A & $\mathrm{NSDWw}_{\mathrm{w}}$ \\
\hline UoB & UNIS 2009-73 & $\mathrm{N} / \mathrm{A}$ & Svalbard & shelf & 04.09.2009 & $80.27,410$ & $12.46,836$ & N/A & N/A & $\begin{array}{l}\text { RP- } \\
\text { EBS }\end{array}$ & 452 & N/A & $\mathrm{N} / \mathrm{A}$ & N/A & N/A & NSDWw \\
\hline UоB & UNIS 2007-140 & $\mathrm{N} / \mathrm{A}$ & Svalbard & shelf & 04.09.2007 & $80.38,915$ & $22.06,067$ & N/A & N/A & $\begin{array}{l}\text { RP- } \\
\text { EBS }\end{array}$ & 126 & N/A & $\mathrm{N} / \mathrm{A}$ & N/A & N/A & $\mathrm{NSDWw}_{\mathrm{w}}$ \\
\hline UoB & VGPT1-22 2009 & Sektor 4 & Continental shelf (Norway) & shelf & 29.05 .2009 & $61.23,724$ & $02.07,254$ & $\mathrm{~N} / \mathrm{A}$ & N/A & Grab & 295 & $\mathrm{~N} / \mathrm{A}$ & N/A & $\mathrm{N} / \mathrm{A}$ & N/A & Norwegian Coastal Current \\
\hline UoB & VGPT2-10 2011 & $\mathrm{~N} / \mathrm{A}$ & Continental shelf (Norway) & shelf & 28.05 .2011 & $61.22,632$ & $02.06,582$ & N/A & $\mathrm{N} / \mathrm{A}$ & Grab & 284 & N/A & $\mathrm{N} / \mathrm{A}$ & N/A & $\mathrm{N} / \mathrm{A}$ & Norwegian Coastal Current \\
\hline UoB & VI-22 2011 & Sektor 4 & Continental shelf (Norway) & shelf & 26.05 .2011 & $61.22,140$ & $02.26,688$ & $\mathrm{~N} / \mathrm{A}$ & $\mathrm{N} / \mathrm{A}$ & Grab & 334 & N/A & $\mathrm{N} / \mathrm{A}$ & N/A & $\mathrm{N} / \mathrm{A}$ & Norwegian Coastal Current \\
\hline
\end{tabular}




\section{Table 2 (on next page)}

Information on cumacean specimens included in the molecular species delimitation based on $16 \mathrm{~S}$ rRNA gene region sequences.

Species ID groups specimens assigned morphologically to the same species and letters (A-C) show separated lineages by genetic analyses. Sequence ID identifies each specimen in the conducted phylogenetic analyses. Outgroup sequences of other peracarids (Amphipoda, Isopoda, Tanaidacea) are highlighted in grey. 


\begin{tabular}{|c|c|c|c|c|c|c|c|}
\hline $\begin{array}{l}\text { Species } \\
\text { ID }\end{array}$ & Project & Station & Sample ID & $\begin{array}{l}\text { GenBank } \\
\text { Accession }\end{array}$ & Higher taxon & Putative species & $\begin{array}{l}\text { Sequence ID } \\
\text { (Field ID) }\end{array}$ \\
\hline $\mathrm{NA}$ & NA & NA & NA & HQ450558 & Bodotriidae & Atlantocuma sp. & HQ450558 \\
\hline Bod01 & IceAGE & 983 & DZMB-HH-68412 & MZ402659 & Bodotriidae & Bathycuma brevirostre & ICE1-Bod004 \\
\hline Bod03 & IceAGE & 1072 & DZMB-HH-68361 & MZ402660 & Bodotriidae & Bodotriidae sp. 1 & ICE1-Bod003 \\
\hline NA & NA & $\mathrm{NA}$ & NA & AJ388111 & Bodotriidae & Cumopsis fagei & AJ388111 \\
\hline Bod05-B & IceAGE & 983 & DZMB-HH-68410 & MZ402681 & Bodotriidae & Cyclaspis longicaudata & ICE1-Bod001 \\
\hline Bod05-B & IceAGE & 983 & DZMB-HH-68411 & MZ402680 & Bodotriidae & Cyclaspis longicaudata & ICE1-Bod002 \\
\hline Bod05-A & UoB & 11.05.15-1 & Bio material $=4-6$ & MK613872.1 & Bodotriidae & Cyclaspis longicaudata & seq2 \\
\hline Bod05-A & UoB & VI-22 2011 & Bio material=7-8 & MK613873.1 & Bodotriidae & Cyclaspis longicaudata & seq3 \\
\hline NA & NA & $\mathrm{NA}$ & NA & HQ450557 & Bodotriidae & Cyclaspis sp. & HQ450557 \\
\hline Bod06 & UoB & KV-09 2011 & Bio material=146 & MK613886.1 & Bodotriidae & Iphinoe serrata & seq4 \\
\hline Cer01 & IceAGE & 1057 & DZMB-HH-68388 & MZ402679 & Ceratocumatidae & Cimmerius reticulatus & ICE1-Cer001 \\
\hline Cer01 & IceAGE & 1072 & DZMB-HH-68362 & MZ402678 & Ceratocumatidae & Cimmerius reticulatus & ICE1-Cer002 \\
\hline Cer01 & IceAGE & 1072 & DZMB-HH-68349 & MZ402677 & Ceratocumatidae & Cimmerius reticulatus & ICE1-Cer003 \\
\hline Dia01 & UoB & $09.01 .28-2$ & Bio material=160409-8 & MK613898.1 & Diastylidae & Diastylis cornuta & seq25 \\
\hline Dia01 & UoB & VGPT1-22 2009 & Bio material=9-13 & MK613897.1 & Diastylidae & Diastylis cornuta & seq26 \\
\hline Dia03 & UoB & UNIS 2007-129 & Bio material $=031109-12$ & MK613904.1 & Diastylidae & Diastylis goodsiri & seq31 \\
\hline Dia04 & UoB & BS 14-19 & Bio material=21-22 & MK613901.1 & Diastylidae & Diastylis laevis & seq33 \\
\hline Dia05 & UoB & BS $14-19$ & Bio material $=26-28$ & MK613911.1 & Diastylidae & Diastylis lucifera & seq35 \\
\hline Dia06 & IceAGE & 1144 & DZMB-HH-68295 & MZ402685 & Diastylidae & Diastylis polaris & ICE1-Dia010 \\
\hline Dia06 & IceAGE & 1144 & DZMB-HH-68297 & MZ402686 & Diastylidae & Diastylis polaris & ICE1-Dia016 \\
\hline Dia06 & IceAGE & 1184 & DZMB-HH-68262 & MZ402683 & Diastylidae & Diastylis polaris & ICE1-Dia003 \\
\hline Dia06 & IceAGE & 1184 & DZMB-HH-68263 & MZ402682 & Diastylidae & Diastylis polaris & ICE1-Dia006 \\
\hline Dia06 & IceAGE & 1184 & DZMB-HH-68234 & MZ402684 & Diastylidae & Diastylis polaris & ICE1-Dia009 \\
\hline Dia06 & IceAGE & 1191 & DZMB-HH-68259 & MZ402687 & Diastylidae & Diastylis polaris & ICE1-Dia019 \\
\hline Dia06 & UoB & H2DEEP-RP-1 & Bio material=29-31 & MK613902.1 & Diastylidae & Diastylis polaris & seq39 \\
\hline Dia06 & MAREANO & R488-379, BT & Bio material=32-33 & MK613903.1 & Diastylidae & Diastylis polaris & seq40 \\
\hline Dia07 & UoB & UNIS 2009-73 & Bio material $=031109-19$ & MK613905.1 & Diastylidae & Diastylis rathkei & seq36 \\
\hline NA & NA & $\mathrm{NA}$ & $\mathrm{NA}$ & HQ450555 & Diastylidae & Diastylis rathkei & HQ450555 \\
\hline
\end{tabular}




\begin{tabular}{|c|c|c|c|c|c|c|c|}
\hline $\begin{array}{l}\text { Species } \\
\text { ID }\end{array}$ & Project & Station & Sample ID & $\begin{array}{l}\text { GenBank } \\
\text { Accession }\end{array}$ & Higher taxon & Putative species & $\begin{array}{l}\text { Sequence ID } \\
\text { (Field ID) }\end{array}$ \\
\hline NA & $\mathrm{NA}$ & $\mathrm{NA}$ & $\mathrm{NA}$ & U81512 & Diastylidae & Diastylis sculpta & U81512 \\
\hline Dia08 & UoB & UNIS 2007-140 & Bio material $=031109-16$ & MK613906.1 & Diastylidae & Diastylis cf. spinulosa & seq38 \\
\hline Dia09 & UoB & $11.05 .15-1$ & Bio material=35-37 & MK613899.1 & Diastylidae & Diastylis tumida & seq42 \\
\hline Dia09 & MAREANO & R721-126, RP & Bio material=152-153 & MK613900.1 & Diastylidae & Diastylis tumida & seq43 \\
\hline Dia10 & IceAGE & 983 & DZMB-HH-68413 & MZ402689 & Diastylidae & Diastyloides atlanticus & ICE1-Dia011 \\
\hline Dia10 & IceAGE & 983 & DZMB-HH-68434 & MZ402688 & Diastylidae & Diastyloides atlanticus & ICE1-Dia024 \\
\hline Dia11 & UoB & $11.03 .11-2$ & Bio material=D4-D6 & MK613910.1 & Diastylidae & Diastyloides biplicatus & seq44 \\
\hline Dia12 & UoB & $11.05 .10-3$ & Bio material $=38-40$ & MK613907.1 & Diastylidae & Diastyloides serratus & seq47 \\
\hline Dia12 & UoB & $11.05 .11-2 \mathrm{C}$ & Bio material=159, 174 & MK613909.1 & Diastylidae & Diastyloides serratus & seq48 \\
\hline Dia12 & UoB & BS $82-147$ & Bio material=1004-1006 & MK613908.1 & Diastylidae & Diastyloides serratus & seq49 \\
\hline NA & NA & $\mathrm{NA}$ & NA & HQ450556 & Diastylidae & Diastylopsis sp. & HQ450556 \\
\hline Dia14 & IceAGE & 1123 & DZMB-HH-68456 & MZ402704 & Diastylidae & Leptostylis ampullacea & ICE1-Dia018 \\
\hline Dia14 & IceAGE & 1123 & DZMB-HH-68443 & MZ402711 & Diastylidae & Leptostylis ampullacea & ICE1-Dia001 \\
\hline Dia14 & IceAGE & 1123 & DZMB-HH-68445 & MZ402708 & Diastylidae & Leptostylis ampullacea & ICE1-Dia007 \\
\hline Dia14 & IceAGE & 1136 & DZMB-HH-68266 & MZ402710 & Diastylidae & Leptostylis ampullacea & ICE1-Dia002 \\
\hline Dia14 & IceAGE & 1136 & DZMB-HH-68267 & MZ402709 & Diastylidae & Leptostylis ampullacea & ICE1-Dia005 \\
\hline Dia14 & IceAGE & 1136 & DZMB-HH-68268 & MZ402707 & Diastylidae & Leptostylis ampullacea & ICE1-Dia008 \\
\hline Dia14 & IceAGE & 1144 & DZMB-HH-68296 & MZ402706 & Diastylidae & Leptostylis ampullacea & ICE1-Dia013 \\
\hline Dia14 & IceAGE & 1191 & DZMB-HH-68258 & MZ402705 & Diastylidae & Leptostylis ampullacea & ICE1-Dia014 \\
\hline Dia15 & IceAGE & 1136 & DZMB-HH-68269 & MZ402712 & Diastylidae & Leptostylis borealis & ICE1-Dia015 \\
\hline Dia15 & IceAGE & 1219 & DZMB-HH-68403 & MZ402713 & Diastylidae & Leptostylis borealis & ICE1-Dia017 \\
\hline Dia16-A & UoB & $11.05 .10-1$ & Bio material $=41-43$ & MK613921.1 & Diastylidae & Leptostylis longimana & seq52 \\
\hline Dia16-A & UoB & BS $82-147$ & Bio material $=49-50$ & MK613922.1 & Diastylidae & Leptostylis longimana & seq53 \\
\hline Dia16-B & PASCAL & $24 / 5$ & DZMB-HH-63369 & MZ402723 & Diastylidae & Leptostylis cf. longimana & P-Dias001 \\
\hline Dia16-B & PASCAL & $24 / 5$ & DZMB-HH-63370 & MZ402714 & Diastylidae & Leptostylis cf. longimana & P-Dias002 \\
\hline Dia16-B & PASCAL & $24 / 5$ & DZMB-HH-59943 & MZ402722 & Diastylidae & Leptostylis cf. longimana & P-Dias028 \\
\hline Dia16-B & PASCAL & $24 / 5$ & DZMB-HH-63371 & MZ402717 & Diastylidae & Leptostylis cf. longimana & P-Dias032 \\
\hline Dia16-B & PASCAL & $25 / 5$ & DZMB-HH-59218 & MZ402718 & Diastylidae & Leptostylis cf. longimana & P-Dias007 \\
\hline Dia16-B & PASCAL & $30 / 1$ & DZMB-HH-63337 & MZ402716 & Diastylidae & Leptostylis cf. longimana & P-Dias003 \\
\hline
\end{tabular}




\begin{tabular}{|c|c|c|c|c|c|c|c|}
\hline $\begin{array}{l}\text { Species } \\
\text { ID }\end{array}$ & Project & Station & Sample ID & $\begin{array}{l}\text { GenBank } \\
\text { Accession }\end{array}$ & Higher taxon & Putative species & $\begin{array}{l}\text { Sequence ID } \\
\text { (Field ID) }\end{array}$ \\
\hline Dia16-B & PASCAL & $30 / 1$ & DZMB-HH-59533 & MZ402719 & Diastylidae & Leptostylis cf. longimana & P-Dias027 \\
\hline Dia16-B & PASCAL & $30 / 1$ & DZMB-HH-63343 & MZ402720 & Diastylidae & Leptostylis cf. longimana & P-Dias031 \\
\hline Dia16-B & PASCAL & $32 / 3$ & DZMB-HH-63330 & MZ402721 & Diastylidae & Leptostylis cf. longimana & P-Dias004 \\
\hline Dia16-B & PASCAL & $32 / 3$ & DZMB-HH-63331 & MZ402724 & Diastylidae & Leptostylis cf. longimana & P-Dias029 \\
\hline Dia16-B & PASCAL & $32 / 3$ & DZMB-HH-63334 & MZ402715 & Diastylidae & Leptostylis cf. longimana & P-Dias030 \\
\hline Dia17 & IceAGE & 983 & DZMB-HH-68414 & MZ402702 & Diastylidae & Leptostylis sp. 1 & ICE1-Dia012 \\
\hline Dia17 & IceAGE & 983 & DZMB-HH-68418 & MZ402701 & Diastylidae & Leptostylis sp. 1 & ICE1-Dia025 \\
\hline Lam01 & Alaska & 90626 & Bio material=200912-9 & MK613925.1 & Lampropidae & Alamprops augustinensis & seq87 \\
\hline Lam02 & IceAGE & 983 & DZMB-HH-68421 & MZ402676 & Lampropidae & Chalarostylis elegans & ICE1-Lam009 \\
\hline Lam02 & IceAGE & 983 & DZMB-HH-68424 & MZ402675 & Lampropidae & Chalarostylis elegans & ICE1-Lam017 \\
\hline Lam04 & UoB & BIOICE3669 & Bio material=187-188, ma6 & MK613924.1 & Lampropidae & Hemilamprops assimilis & seq80 \\
\hline Lam05-A & UoB & BS $86-151$ & Bio material $=63-64$ & MK613913.1 & Lampropidae & Hemilamprops cristatus & seq81 \\
\hline Lam05-A & UoB & BS $86-151$ & Bio material $=65$ & MK613914.1 & Lampropidae & Hemilamprops cristatus & seq82 \\
\hline Lam05-B & IceAGE & 983 & DZMB-HH-68420 & MZ402695 & Lampropidae & Hemilamprops cf. cristatus & ICE1-Lam002 \\
\hline Lam05-B & IceAGE & 983 & DZMB-HH-68436 & MZ402696 & Lampropidae & Hemilamprops cf. cristatus & ICE1-Lam008 \\
\hline Lam05-A & IceAGE & 1123 & DZMB-HH-68446 & MZ402697 & Lampropidae & Hemilamprops cf. cristatus & ICE1-Lam018 \\
\hline Lam06 & IceAGE & 983 & DZMB-HH-68419 & MZ402692 & Lampropidae & Hemilamprops cf. diversus & ICE1-Lam001 \\
\hline Lam06 & IceAGE & 983 & DZMB-HH-68435 & MZ402693 & Lampropidae & Hemilamprops cf. diversus & ICE1-Lam006 \\
\hline Lam06 & IceAGE & 983 & DZMB-HH-68422 & MZ402694 & Lampropidae & Hemilamprops cf. diversus & ICE1-Lam010 \\
\hline Lam06 & IceAGE & 983 & DZMB-HH-68423 & MZ402691 & Lampropidae & Hemilamprops cf. diversus & ICE1-Lam011 \\
\hline Lam07 & IceAGE & 1072 & DZMB-HH-68363 & MZ402698 & Lampropidae & Hemilamprops pterini & ICE1-Lam005 \\
\hline Lam07 & IceAGE & 1072 & DZMB-HH-68364 & MZ402699 & Lampropidae & Hemilamprops pterini & ICE1-Lam013 \\
\hline Lam08 & UoB & BS 28-44 & Bio material $=66-67$ & MK613923.1 & Lampropidae & Hemilamprops roseus & seq83 \\
\hline Lam10 & IceAGE & 1072 & DZMB-HH-68365 & MZ402690 & Lampropidae & Hemilamprops sp. 2 & ICE1-Lam015 \\
\hline Lam11 & IceAGE & 1136 & DZMB-HH-68270 & MZ402700 & Lampropidae & Hemilamprops uniplicatus & ICE1-Lam003 \\
\hline Lam11 & UoB & $11.05 .15-1$ & Bio material $=68-70$ & MK613915.1 & Lampropidae & Hemilamprops uniplicatus & seq84 \\
\hline Lam11 & UoB & SFND-08R 2011 & Bio material $=71-72$ & MK613916.1 & Lampropidae & Hemilamprops uniplicatus & seq85 \\
\hline Lam12 & UoB & VGPT1-22 2009 & Bio material $=61-62$ & MK613917.1 & Lampropidae & Mesolamprops denticulatus & seq88 \\
\hline Lam13 & IceAGE & 1072 & DZMB-HH-68366 & MZ402737 & Lampropidae & Platysympus typicus & ICE1-Lam016 \\
\hline
\end{tabular}




\begin{tabular}{|c|c|c|c|c|c|c|c|}
\hline $\begin{array}{l}\text { Species } \\
\text { ID }\end{array}$ & Project & Station & Sample ID & $\begin{array}{l}\text { GenBank } \\
\text { Accession }\end{array}$ & Higher taxon & Putative species & $\begin{array}{l}\text { Sequence ID } \\
\text { (Field ID) }\end{array}$ \\
\hline Lam13 & IceAGE & 1136 & DZMB-HH-68271 & MZ402736 & Lampropidae & Platysympus typicus & ICE1-Lam004 \\
\hline Lam13 & UoB & UNIS 2009-71 & Bio material $=031109-15$ & MK613918.1 & Lampropidae & Platysympus typicus & seq89 \\
\hline Lam13 & MAREANO & R814-22, RP & Bio material $=$ ma14 & MK613919.1 & Lampropidae & Platysympus typicus & seq90 \\
\hline Leu01 & UoB & BS 75-135 & Bio material=79-82 & MK613870.1 & Leuconidae & Eudorella emarginata & seq59 \\
\hline Leu02 & UoB & BS 34-56 & Bio material $=88-93$ & MK613887.1 & Leuconidae & Eudorella hirsuta & seq62 \\
\hline Leu02 & UoB & $11.03 .09-1$ & Bio material=94-96, 102 & MK613888.1 & Leuconidae & Eudorella hirsuta & seq63 \\
\hline NA & NA & NA & NA & U81513 & Leuconidae & Eudorella pusilla & U81513 \\
\hline Leu04-A & UoB & BS $28-44$ & Bio material $=97,99$ & MK613881.1 & Leuconidae & Eudorella truncatula & seq64 \\
\hline Leu04-A & UoB & BS 75-135 & Bio material $=200$ & MK613882.1 & Leuconidae & Eudorella truncatula & seq67 \\
\hline Leu04-B & UoB & 11.01.19.1 & Bio material=100-101 & MK613884.1 & Leuconidae & Eudorella truncatula & seq65 \\
\hline Leu04-B & UoB & $11.01 .21-1$ & Bio material $=1007-1008$ & MK613883.1 & Leuconidae & Eudorella truncatula & seq68 \\
\hline Leu04-C & MAREANO & R754-132, RP & Bio material=ma5 & MK613885.1 & Leuconidae & Eudorella truncatula & seq69 \\
\hline Leu05 & IceAGE & 1123 & DZMB-HH-68457 & MZ402728 & Leuconidae & Leucon (Alytoleucon) pallidus & ICE1-Leu019 \\
\hline Leu05 & IceAGE & 1136 & DZMB-HH-68274 & MZ402729 & Leuconidae & Leucon (Alytoleucon) pallidus & ICE1-Leu002 \\
\hline Leu05 & IceAGE & 1136 & DZMB-HH-68276 & MZ402731 & Leuconidae & Leucon (Alytoleucon) pallidus & ICE1-Leu005 \\
\hline Leu05 & IceAGE & 1136 & DZMB-HH-68278 & NA & Leuconidae & Leucon (Alytoleucon) pallidus & ICE1-Leu008 \\
\hline Leu05 & IceAGE & 1144 & DZMB-HH-68298 & MZ402730 & Leuconidae & Leucon (Alytoleucon) pallidus & ICE1-Leu003 \\
\hline Leu05 & IceAGE & 1144 & DZMB-HH-68299 & MZ402725 & Leuconidae & Leucon (Alytoleucon) pallidus & ICE1-Leu006 \\
\hline Leu05 & IceAGE & 1144 & DZMB-HH-68300 & MZ402726 & Leuconidae & Leucon (Alytoleucon) pallidus & ICE1-Leu009 \\
\hline Leu05 & IceAGE & 1219 & DZMB-HH-68404 & MZ402727 & Leuconidae & Leucon (Alytoleucon) pallidus & ICE1-Leu010 \\
\hline Leu05 & UoB & BS $82-147$ & Bio material $=1001-1003$ & MK613892.1 & Leuconidae & Leucon (Alytoleucon) pallidus & seq77 \\
\hline Leu05 & UoB & 11.01.19.1 & Bio material=117-119 & MK613891.1 & Leuconidae & Leucon (Alytoleucon) pallidus & seq78 \\
\hline NA & NA & NA & NA & HQ450522 & Leuconidae & Leucon (Crymoleucon) antarcticus & HQ450522 \\
\hline NA & NA & NA & NA & HQ450543 & Leuconidae & Leucon (Crymoleucon) intermedius & HQ450543 \\
\hline NA & NA & NA & NA & HQ450549 & Leuconidae & Leucon (Crymoleucon) intermedius & HQ450549 \\
\hline NA & NA & NA & NA & HQ450550 & Leuconidae & Leucon (Crymoleucon) intermedius & HQ450550 \\
\hline NA & NA & NA & NA & HQ450537 & Leuconidae & Leucon (Crymoleucon) rossi & HQ450537 \\
\hline Leu07 & UoB & BS 22-32 & Bio material=103-108 & MK613889.1 & Leuconidae & Leucon (Leucon) acutirostris & seq70 \\
\hline NA & NA & NA & NA & HQ450551 & Leuconidae & Leucon (Leucon) assimilis & HQ450551 \\
\hline
\end{tabular}




\begin{tabular}{|c|c|c|c|c|c|c|c|}
\hline $\begin{array}{l}\text { Species } \\
\text { ID }\end{array}$ & Project & Station & Sample ID & $\begin{array}{l}\text { GenBank } \\
\text { Accession }\end{array}$ & Higher taxon & Putative species & $\begin{array}{l}\text { Sequence ID } \\
\text { (Field ID) }\end{array}$ \\
\hline$\overline{\mathrm{NA}}$ & $\overline{N A}$ & $\mathrm{NA}$ & NA & HQ450552 & Leuconidae & Leucon (Leucon) assimilis & HQ450552 \\
\hline NA & NA & NA & NA & HQ450553 & Leuconidae & Leucon (Leucon) assimilis & HQ450553 \\
\hline Leu08 & UoB & $09.01 .28-2$ & Bio material=109-111 & MK613895.1 & Leuconidae & Leucon (Leucon) nathorsti & seq72 \\
\hline Leu08 & UoB & BS 75-135 & Bio material=112-114 & MK613893.1 & Leuconidae & Leucon (Leucon) nathorsti & seq73 \\
\hline Leu09 & UoB & UNIS 2009-27 & Bio material $=031109-9$ & MK613894.1 & Leuconidae & Leucon (Leucon) aff. nathorsti & seq75 \\
\hline Leu10 & UoB & UNIS2009-4 & Bio material=115-116 & MK613890.1 & Leuconidae & Leucon (Leucon) nasicoides & seq74 \\
\hline Leu11 & IceAGE & 1136 & DZMB-HH-68273 & MZ402734 & Leuconidae & Leucon (Leucon) profundus & ICE1-Leu001 \\
\hline Leu11 & IceAGE & 1136 & DZMB-HH-68275 & MZ402732 & Leuconidae & Leucon (Leucon) profundus & ICE1-Leu004 \\
\hline Leu11 & IceAGE & 1136 & DZMB-HH-68277 & MZ402733 & Leuconidae & Leucon (Leucon) profundus & ICE1-Leu007 \\
\hline Leu14 & IceAGE & 1123 & DZMB-HH-68449 & MZ402735 & Leuconidae & Leucon (Macrauloleucon) spinulosus & ICE1-Leu018 \\
\hline NA & NA & NA & NA & HQ450554 & Leuconidae & Leucon sp. & HQ450554 \\
\hline Nan03 & UoB & BS $86-151$ & Bio material=120-122 & MK613876.1 & Nannastacidae & Campylaspis costata & seq6 \\
\hline Nan04 & UoB & BS 34-56 & Bio material=1-3 & MK613874.1 & Nannastacidae & Campylaspis globosa & seq9 \\
\hline Nan04 & IceAGE & 1057 & DZMB-HH-68390 & MZ402662 & Nannastacidae & Campylaspis cf. globosa & ICE1-Nann014 \\
\hline Nan05 & IceAGE & 1057 & DZMB-HH-68389 & MZ402663 & Nannastacidae & Campylaspis horrida & ICE1-Nann013 \\
\hline Nan05 & MAREANO & R721-126, RP & Bio material=123 & MK613877.1 & Nannastacidae & Campylaspis horrida & seq10 \\
\hline Nan06 & PASCAL & $24 / 5$ & DZMB-HH-63414 & MZ402664 & Nannastacidae & Campylaspis intermedia & P-Nann009 \\
\hline Nan07 & PASCAL & $24 / 5$ & DZMB-HH-63399 & MZ402666 & Nannastacidae & Campylaspis rubicunda & P-Nann001 \\
\hline Nan07 & PASCAL & $24 / 5$ & DZMB-HH-63400 & MZ402665 & Nannastacidae & Campylaspis rubicunda & P-Nann002 \\
\hline Nan07 & PASCAL & $24 / 5$ & DZMB-HH-63401 & MZ402670 & Nannastacidae & Campylaspis rubicunda & P-Nann003 \\
\hline Nan07 & PASCAL & $24 / 5$ & DZMB-HH-63402 & MZ402669 & Nannastacidae & Campylaspis rubicunda & P-Nann004 \\
\hline Nan07 & PASCAL & $24 / 5$ & DZMB-HH-63405 & MZ402667 & Nannastacidae & Campylaspis rubicunda & P-Nann006 \\
\hline Nan07 & PASCAL & $24 / 5$ & DZMB-HH-59833 & MZ402668 & Nannastacidae & Campylaspis rubicunda & P-Nann011 \\
\hline Nan07 & PASCAL & $24 / 5$ & DZMB-HH-63357 & MZ402671 & Nannastacidae & Campylaspis rubicunda & P-Nann012 \\
\hline Nan09 & IceAGE & 1072 & DZMB-HH-68369 & MZ402661 & Nannastacidae & Campylaspis sp. 2 & ICE1-Nann005 \\
\hline Nan10 & IceAGE & 1136 & DZMB-HH-68280 & MZ402672 & Nannastacidae & Campylaspis sulcata & ICE1-Nann002 \\
\hline Nan10 & IceAGE & 1136 & DZMB-HH-68281 & MZ402674 & Nannastacidae & Campylaspis sulcata & ICE1-Nann004 \\
\hline Nan10 & IceAGE & 1136 & DZMB-HH-68282 & MZ402673 & Nannastacidae & Campylaspis sulcata & ICE1-Nann006 \\
\hline Nan10 & UoB & $11.05 .15-1$ & Bio material=134-139 & MK613875.1 & Nannastacidae & Campylaspis sulcata & seq14 \\
\hline
\end{tabular}




\begin{tabular}{llllllll}
$\begin{array}{l}\text { Species } \\
\text { ID }\end{array}$ & Project & Station & Sample ID & $\begin{array}{l}\text { GenBank } \\
\text { Accession }\end{array}$ & Higher taxon & Putative species & $\begin{array}{l}\text { Sequence ID } \\
\text { (Field ID) }\end{array}$ \\
\hline Nan11 & UoB & $11.05 .15-1$ & Bio material=140-145 & MK613878.1 & Nannastacidae & Campylaspis undata & seq21 \\
Nan18 & IceAGE & 1072 & DZMB-HH-68370 & MZ402738 & Nannastacidae & $\begin{array}{l}\text { Styloptocuma gracillimum } \\
\text { ICE1-Nann008 }\end{array}$ \\
Pse01 & UoB & UNIS 2009-36 & Bio material=156-158 & MK613871.1 & Pseudocumatidae & Petalosarsia declivis & seq5 \\
NA & NA & NA & NA & AJ388110 & Tanaidacea & Apseudopsis latreillii & AJ388110 \\
NA & NA & NA & NA & DQ305106 & Isopoda & Asellus (Asellus) aquaticus & DQ305106 \\
NA & NA & NA & NA & AF260869 & Isopoda & Colubotelson thompsoni & AF260869 \\
NA & NA & NA & NA & AF260870 & Isopoda & Crenoicus buntiae & AF260870 \\
NA & NA & NA & NA & AY693421 & Isopoda & Haploniscus sp. & AY693421 \\
NA & NA & NA & NA & AF259533 & Isopoda & Paramphisopus palustris & AF259533 \\
NA & NA & NA & NA & DQ305111 & Isopoda & Proasellus remyi remyi & DQ305111 \\
NA & NA & NA & NA & MK813124 & Amphipoda & Amphipoda sp. & MK813124
\end{tabular}




\section{Table 3(on next page)}

Summary of datasets I-V.

Number of sequences and the resulting alignment length in base pairs integrated in the Bayesian phylogenetic analyses. 


\begin{tabular}{clrrrr} 
Dataset & Taxa & $\begin{array}{l}\text { Sequences } \\
\text { for topology } \\
\text { [n] }\end{array}$ & $\begin{array}{l}\text { Outgroup } \\
\text { sequences } \\
\text { [n] }\end{array}$ & $\begin{array}{l}\text { Alignment } \\
\text { length } \\
\text { [bp] }\end{array}$ \\
\hline I & All Cumacea cumulative set & 155 & 8 & 598 \\
II & Leuconidae & 38 & 1 & 525 \\
III & Bodotriidae and Nannastacidae & 31 & 1 & 524 \\
IV & Diastylidae and Pseudocumatidae & 53 & 1 & 549 \\
V & Ceratocumatidae and Lampropidae & 29 & 1 & 525 \\
\hline
\end{tabular}

1 


\section{Table 4 (on next page)}

Summary of taxonomic incongruences, morphological variability, and potential cryptic diversity cases. 


\begin{tabular}{|c|c|c|c|c|c|}
\hline Species ID & Putative species & Sequence ID (Field ID) & Region & $\begin{array}{c}\text { Depth } \\
\text { range } \\
{[\mathrm{m}]}\end{array}$ & Water mass \\
\hline \multicolumn{6}{|c|}{ Taxonomic incongruences } \\
\hline \multirow{5}{*}{$\begin{array}{c}\text { Dia06 } \\
\text { (Fig. 11-C) }\end{array}$} & \multirow{5}{*}{$\begin{array}{l}\text { Diastylis polaris } \\
\text { aka } \\
\text { 'Diastylis stygia' }\end{array}$} & seq39 & Jan Mayen (Norway) & 2542 & Arctic, Subarctic \\
\hline & & seq40 & Eggakanten (Norway) & 2241 & Subarctic \\
\hline & & $\begin{array}{l}\text { ICE1-Dia003, ICE1-Dia006, } \\
\text { ICE1-Dia009 }\end{array}$ & Norwegian Sea Basin & 1819 & Subarctic \\
\hline & & ICE1-Dia010, ICE1-Dia016 & $\begin{array}{l}\text { East Greenland Denmark } \\
\text { Strait }\end{array}$ & 1281 & Arctic, Subarctic \\
\hline & & ICE1-Dia019 & $\begin{array}{l}\text { North-East Iceland } \\
\text { Norwegian Sea }\end{array}$ & 1574 & Subarctic \\
\hline \multirow{4}{*}{$\begin{array}{l}\text { Lam13 } \\
\text { (Fig. 11-E) }\end{array}$} & \multirow{4}{*}{$\begin{array}{c}\text { Platysympus typicus } \\
\text { aka } \\
\text { 'Platysympus tricarinatus' }\end{array}$} & ICE1-Lam004 & $\begin{array}{l}\text { East Greenland Denmark } \\
\text { Strait }\end{array}$ & 315 & Arctic, Subarctic \\
\hline & & ICE1-Lam016 & $\begin{array}{l}\text { South Iceland Irminger } \\
\text { Basin }\end{array}$ & 1593 & North Atlantic \\
\hline & & seq89 & Svalbard & 497 & Arctic \\
\hline & & seq90 & Continental Shelf (Norway) & 224 & North Atlantic \\
\hline \multicolumn{6}{|c|}{ Morphological variability } \\
\hline \multirow{2}{*}{$\begin{array}{c}\text { Dia14 } \\
\text { (Fig. 11-B) } \\
\& \\
\text { Dia16-B } \\
\text { (Fig. 11-A) }\end{array}$} & Leptostylis ampullacea & $\begin{array}{l}\text { ICE1-Dia018, ICE1-Dia002, } \\
\text { ICE1-Dia005, ICE1-Dia008, } \\
\text { ICE1-Dia001, ICE1-Dia004, } \\
\text { ICE1-Dia007, ICE1-Dia013, } \\
\text { ICE1-Dia014 }\end{array}$ & North East Iceland & $\begin{array}{r}700- \\
1500\end{array}$ & Arctic, Subarctic \\
\hline & Leptostylis cf. Iongimana $B$ & $\begin{array}{l}\text { P-Dias001, P-Dias002, P- } \\
\text { Dias028, P-Dias032, P- } \\
\text { Dias007, P-Dias027, P- } \\
\text { Dias031, P-Dias003, P- } \\
\text { Dias029, P-Dias030 }\end{array}$ & Yermak-Plateau (Svalbard) & $\begin{array}{r}700- \\
1500\end{array}$ & Arctic \\
\hline \multirow{2}{*}{$\begin{array}{c}\text { Leu08 } \\
\text { \& Leu09 } \\
\text { (Fig. S2-W) }\end{array}$} & Leucon nathorsti & seq72, seq 73 & Fanafjorden, Skagerak & $180-246$ & North Atlantic \\
\hline & Leucon aff. nathorsti & $\operatorname{seq} 75$ & Svalbard & 56 & Subarctic \\
\hline \multicolumn{6}{|c|}{ Morphological \& molecular data: cryptic diversity } \\
\hline \multirow{3}{*}{$\begin{array}{l}\text { Leu04-A/- } \\
\text { B/-C } \\
\text { (Fig. S2-U) }\end{array}$} & Eudorella truncatula $A$ & seq64, seq67 & Skagerak & 250 & North Atlantic \\
\hline & Eudorella truncatula $B$ & seq65, seq68 & Fensfjorden, Hjeltefjorden & $200-400$ & North Atlantic \\
\hline & Eudorella truncatula $\mathrm{C}$ & seq69 & Northern Norway & 800 & Subarctic \\
\hline \multirow{2}{*}{$\begin{array}{l}\text { Bod05-A/- } \\
\text { B } \\
\text { (Fig. 13-E) } \\
\end{array}$} & Cyclaspis longicaudata A & seq2, seq3 & Hjeltefjorden & $240-330$ & North Atlantic \\
\hline & Cyclaspis longicaudata $B$ & ICE1-Bod001, ICE1-Bod002 & South Iceland Basin & 2500 & North Atlantic \\
\hline \multirow{2}{*}{$\begin{array}{l}\text { Dia15-A/- } \\
\text { B } \\
\text { (Fig. 12-A) } \\
\end{array}$} & Leptostylis borealis A & ICE1-Dia015 & Greenland shelf & 300 & Subarctic \\
\hline & Leptostylis borealis B & ICE1-Dia017 & North East Iceland & 500 & Subarctic \\
\hline \multirow{2}{*}{$\begin{array}{l}\text { Dia17-A/- } \\
\text { B } \\
\text { (Fig. S2-L) } \\
\end{array}$} & Leptostylis sp. 1 A & ICE1-Dia012 & South Iceland Basin & 2500 & North Atlantic \\
\hline & Leptostylis sp. 1 B & ICE1-Dia025 & South Iceland Basin & 2500 & North Atlantic \\
\hline \multirow[t]{2}{*}{$\begin{array}{l}\text { Dia16-A/- } \\
\text { B } \\
\text { (Fig. 11-A) }\end{array}$} & Leptostylis cf. longimana B & $\begin{array}{l}\text { P-Dias001, P-Dias002, P- } \\
\text { Dias028, P-Dias032, P- } \\
\text { Dias007, P-Dias027, P- } \\
\text { Dias031, P-Dias003, P- } \\
\text { Dias029, P-Dias030 }\end{array}$ & Yermak-Plateau (Svalbard) & $\begin{array}{r}700- \\
1500\end{array}$ & Arctic, Subarctic \\
\hline & Leptostylis longimana A & seq52, seq53 & Sognesjøen \& Skagerak & 500 & North Atlantic \\
\hline $\begin{array}{l}\text { Lam05-A/- } \\
\text { B } \\
\text { (Fig. 11-F) } \\
\end{array}$ & $\begin{array}{l}\text { Hemilamprops cristatus/ } \\
\text { Hemilamprops cf. cristatus }\end{array}$ & seq81, seq82, ICE1-Lam018 & Skagerak \& Greenland slope & 700 & North Atlantic, Subarctic \\
\hline Lam05-B & Hemilamprops cf. cristatus & ICE1-Lam002, ICE1-Lam008 & South Iceland Basin & 2500 & North Atlantic \\
\hline
\end{tabular}




\begin{tabular}{|c|c|c|c|c|c|}
\hline Species ID & Putative species & Sequence ID (Field ID) & Region & $\begin{array}{c}\text { Depth } \\
\text { range } \\
{[\mathrm{m}]}\end{array}$ & Water mass \\
\hline
\end{tabular}

1 


\section{Table 5 (on next page)}

Table related to Fig.10: Total number of representative species per ecoregion as well as shared representatives occurring within several ecoregions. 
Ecoregions

1 Arctic Basin

2 East Greenland Sea

4 North Atlantic Ocean

5 Norwegian Sea

\begin{tabular}{|c|c|c|}
\hline $\begin{array}{l}1 \text { Arctic Basin } \\
2 \text { East Greenland Sea }\end{array}$ & 1 & Diastylis spinulosa \\
\hline $\begin{array}{l}1 \text { Arctic Basin } \\
4 \text { North Atlantic Ocean }\end{array}$ & 1 & Campylaspis intermedia \\
\hline $\begin{array}{l}2 \text { East Greenland Sea } \\
4 \text { North Atlantic Ocean }\end{array}$ & 4 & $\begin{array}{l}\text { Hemilamprops sp.1 (juv.), Hemilamprops cf. cristatus, Leucon } \\
\text { (Macrauloleucon) spinulosus, Leptostylis ampullacea }\end{array}$ \\
\hline $\begin{array}{l}2 \text { East Greenland Sea } \\
\mathbf{5} \text { Norwegian Sea }\end{array}$ & 4 & $\begin{array}{l}\text { Hemilamprops uniplicatus, Diastylis polaris, Campylaspis sulcata, } \\
\text { Campylaspis undata }\end{array}$ \\
\hline $\begin{array}{l}4 \text { North Atlantic Ocean } \\
5 \text { Norwegian Sea }\end{array}$ & 6 & $\begin{array}{l}\text { Leptostylis longimana, Diastyloides serratus, Leucon (Leucon) } \\
\text { nathorsti, Eudorella hirsuta, Campylaspis horrida, Eudorella } \\
\text { truncatula }\end{array}$ \\
\hline 1 Arctic Basin & 7 & $\begin{array}{l}\text { Diastylis goodsiri, Petalosarsia declivis, Leucon (Leucon) nasicoides, } \\
\text { Diastylis rathkei, Leptostylis cf. longimana, Campylaspis rubicunda, } \\
\text { Leucon (Leucon) aff. nathorsti }\end{array}$ \\
\hline 2 East Greenland Sea & 5 & $\begin{array}{l}\text { Leucon (Leucon) profundus, Campylaspis sp.1, Hemilamprops } \\
\text { assimilis, Diastylis echinata, Leptostylis borealis }\end{array}$ \\
\hline 4 North Atlantic Ocean & 42 & $\begin{array}{l}\text { Bathycuma brevirostre, Campylaspides sp.1, Diastylis lucifera, } \\
\text { Chalarostylis sp.1, Cumellopsis cf. puritani, Eudorella emarginata, } \\
\text { Hemilamprops cf. diversus, Hemilamprops pterini, Leucon } \\
\text { (Crymoleucon) tener, Eudorella sp.1, Diastyloides atlanticus, } \\
\text { Hemilamprops roseus, Bodotriidae sp.1, Leptostylis sp.2, Cimmerius } \\
\text { reticulatus, Campylaspis sp.2, Styloptocuma sp.1, Leptostylis sp.1, } \\
\text { Leucon sp.1, Cyclaspis longicaudata B, Bodotriidae sp.2, } \\
\text { Procampylaspis ommidion, Styloptocuma gracillimum, Leucon } \\
\text { (Leucon) acutirostris, Leucon (Leucon) cf. robustus, Leucon } \\
\text { (Macrauloleucon) siphonatus, Procampylaspis sp.1, Makrokylindrus } \\
\text { (Makrokylindrus) spiniventris, Chalarostylis elegans, Styloptocuma } \\
\text { erectum, Hemilamprops sp.2, Platytyphlops semiornatus, } \\
\text { Nannastacidae sp.1, Campylaspis alba, Bathycuma sp.1, } \\
\text { Styloptocuma sp. 2, Diastylis laevis, Diastyloides sp.1, Campylaspis } \\
\text { globosa, Campylaspis costata, Pseudocuma sp.1, Cumella (Cumella) } \\
\text { cf. decipiens }\end{array}$ \\
\hline 5 Norwegian Sea & 6 & $\begin{array}{l}\text { Iphinoe serrata, Diastyloides biplicatus, Cyclaspis longicaudata A, } \\
\text { Mesolamprops denticulatus, Diastylis cornuta, Diastylis tumida }\end{array}$ \\
\hline
\end{tabular}

Total Representative species

2 Platysympus typicus, Leucon (Alytoleucon) pallidus

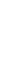

